\title{
Climatic drivers of seasonal glacier mass balances: an analysis of 6 decades at Glacier de Sarennes (French Alps)
}

\author{
E. Thibert ${ }^{1}$, N. Eckert ${ }^{1}$, and C. Vincent ${ }^{2}$ \\ ${ }^{1}$ IRSTEA, UR ETGR Erosion Torrentielle Neige et Avalanches, BP 76, 2 rue de la papeterie, \\ Saint Martin d'Hères, France \\ ${ }^{2}$ CNRS/UJF-Grenoble 1, LGGE Laboratoire de Glaciologie et Géophysique de l'Environnement, BP 96, \\ 54 rue Molières, Saint Martin d'Hères, France \\ Correspondence to: E. Thibert (emmanuel.thibert@ irstea.fr)
}

Received: 7 May 2012 - Published in The Cryosphere Discuss.: 14 June 2012

Revised: 11 December 2012 - Accepted: 12 December 2012 - Published: 15 January 2013

\begin{abstract}
Refined temporal signals extracted from a winter and summer mass balance series recorded at Glacier de Sarennes (French Alps) using variance decomposition are related to local meteorological data and large-scale North Atlantic Oscillation (NAO) anomalies in terms of interannual variability, trends of the low-frequency signals, and breaks in the time series. The winter balance has increased by $+23 \%$ since 1976 due to more precipitation in early and late winter. The summer balance has decreased since 1982 due to a $43 \%$ increase in snow and ice melt. A 24-day lengthening of the ablation period - mainly due to longer ice ablation - is the main component in the overall increase in ablation. In addition, the last $25 \mathrm{yr}$ have seen increases in ablation rates of 14 and $10 \%$ for snow and ice, respectively. A simple degree-day analysis can account for both the snow/ice melt rate rise and the lengthening of the ablation period as a function of higher air temperatures. From the same analysis, the equilibriumline altitude of this $45^{\circ} \mathrm{N}$ latitude south-facing glacier has a sensitivity to temperature of $+93 \mathrm{~m}^{\circ} \mathrm{C}^{-1}$ around its mean elevation of $3100 \mathrm{~m}$ a.s.l. over 6 decades. The sensitivity of summer balance to temperature is $-0.62 \mathrm{~m}$ w.e. $\mathrm{yr}^{-1}{ }^{\circ} \mathrm{C}^{-1}$ for a typical 125-day-long ablation season. Finally, the correlation of winter and summer mass balance terms with NAO anomalies is investigated. Singularly, highest values are obtained between winter NAO anomalies and summer balance. Winter NAO anomalies and winter balance and precipitation are almost disconnected. However, these results strongly depend on how the NAO signal is smoothed, so that the link between Sarennes mass balance seasonal terms and NAO signal remains tenuous and hard to interpret.
\end{abstract}

\section{Introduction}

Mountain glaciers are recognised as excellent indicators of climate change over the last few centuries (Oerlemans and Fortuin, 1992; Haeberli, 1995; Vincent, 2002; IPCC, 2007). Glacier length fluctuations are the oldest and most numerous measurements (Oerlemans et al., 1998), but they provide a climatic signal that is delayed, filtered (high frequency cutting) and dependent on glacier dynamics (Johannesson et al., 1989). In contrast, surface mass balance is a more direct climatic signal. From a thermodynamic point of view, a glacier is an open system which exchanges mass and energy with its environment. As most Alpine glaciers are temperate (with the temperature at the melting point), energy exchanges (radiation and sensible heat) result mainly in a loss of mass through melting, while ice condensation and sublimation are negligible in the mass budget of Alpine glaciers (Sicart et al., 2008). Winter precipitation recorded in the accumulation term accounts for almost all the overall system mass input (Braithwaite, 1981; Oerlemans, 1993, 2001; Vincent and Vallon, 1997; Vincent, 2002). Summer melt variability is mainly dependent on short-wave radiation which correlates well with air temperature (Pelliciotti et al., 2008; Sicart et al., 2008). Glacier mass balance can therefore be used to assess climate warming on a regional scale (Vincent et al., 2004; Huss and Bauder, 2009).

Nevertheless, inferring the climatic signal from a glacier mass balance series is not easy. The glacier-wide mass balance is a convolution between climate evolution and glacier geometry changes in response to climate fluctuations 
(Elsberg et al., 2001; Ohmura et al., 2007; Harrison et al., 2009). As an illustration of the glacier topography feedback, when a glacier tongue retreats, ablation areas of strong negative budget are removed from the average balance, tending to make it less negative. Conversely, a lowering of the glacier surface tends to force the surface energy balance in relation with altitudinal gradient of the mass balance. Moreover, as pointed out by Harrison et al. (2009) and Huss et al. (2012), the combination of these effects can have different results on glacier-wide balance from one glacier to another.

To overcome these artifacts, Elsberg et al. (2001) proposed to relate mass balance to a constant geometry correcting for surface and altitude changes. They successfully made such an adjustment for South Cascade Glacier, and Rasmussen (2009) extended this correction to the two seasonal components of the balance. An alternative is to directly use surface mass balances measured at an individual location and use a single or a few sites (Vincent et al., 2004; Huss and Bauder, 2009). When point-to-point balances are significantly correlated, this local analysis has a glacier-wide significance (Rasmussen, 2004; Rasmussen and Andreassen, 2005; Thibert and Vincent, 2009).

A difficulty is that long data series are affected by missing values of seasonal mass balance in some years at some locations. Missing values in the summer balance term are often estimated with temperature index models (Huss and Bauder, 2009) but, at this stage, a method that does not use meteorological data should be used to extract a self-sufficient unbiased temporal signal and interpret its link with climatic drivers. An interesting option that fits this requirement is analysis of variance (ANOVA) that separates the overall annual effect from spatial variability at the glacier surface (Lliboutry, 1974). Missing values are reconstructed using information from the other measurements at the glacier surface without any assumption concerning meteorological conditions and their relationship to mass balance seasonal components.

Here, we use long seasonal mass balance terms recorded over six decades on Sarennes glacier (French Alps). The time series are provided by the expansion of Lliboutry's model of variance analysis proposed by Eckert et al. (2011) to extract winter and summer terms from recorded winter and annual point measurements. Being performed in a hierarchical context, this approach has the advantage of separating the structured low-frequency temporal signal that affects the whole glacier from random fluctuations in the balance between years and between sites. Hence, the temporal signals obtained include annual glacier-wide fluctuations and underlying time trends and breaks in the time signal.

This paper aims to analyse how these temporal signals are related to annual and regional temperature and precipitation measurements. Potential connections to larger-scale atmospheric patterns are also investigated with respect to North Atlantic Oscillation (NAO) anomalies. Such a link has been reported for Scandinavian and Alpine glaciers by analyzing annual balance series (Pohjola and Rogers, 1997; Washington et al., 2000; Six et al., 2001; Fealy and Sweeney, 2005) and winter balance series (Fealy and Sweeney, 2005). However, large regional differences between the Southwestern and Eastern Alps were found (Marzeion and Nesje, 2012). The special location of Sarennes at the climatic boundary between the southern and northern French Alps and its long record of seasonal balances led us to extend such analyses, focusing on how this link splits for summer and winter mass budgets.

For both local and large-scale atmospheric covariates, correlations are investigated for annual values and for the trends of the low-frequency signals. After a presentation of the site and of the method used to process the data (Sect. 2), this analysis is conducted and discussed for the winter (Sect. 3) and summer (Sect. 4) mass balance components.

\section{Site, data and method}

\subsection{Sarennes mass balance data}

Sarennes is a small south-facing glacier $\left(0.4 \mathrm{~km}^{2}\right.$ in 2003$)$ with a small altitude range of $150 \mathrm{~m}$, located in the Grande Rousses range $\left(45^{\circ} 07^{\prime} \mathrm{N}, 6^{\circ} 07^{\prime} \mathrm{E}\right.$, French Alps). Since 1949 , systematic winter and summer mass balance measurements have been carried out. This makes the Sarennes data series the third longest series of winter and summer mass balances in the Alps after Claridenfirn (Müller and Kappenberger, 1991) and the Aletsch glacier (Aellen and Funk, 1990). On four to five sites (Fig. 1), two different measurement methods are used for accumulation and ablation measurements: (1) cores are first drilled to measure winter mass balances from snow layering (stratigraphy) and density measurements, and (2) annual mass balances are determined from stakes inserted in ice. The summer mass balance is the difference between these two balance terms. Sarennes data have been checked using a geodetic method (Thibert et al., 2008) and have been shown to be consistent. Measurements are repeated 6 to 7 times through the ablation period, not on fixed dates but based on use of the stratigraphic method to determine the maximum balance at the end of winter and minimum at the end of the ablation period (Cogley et al., 2010). Therefore, the numerous observations on the glacier make it possible to decipher changes in the rate and duration of ablation in summer balance variations.

Here we analyse the 1949-2007 data table ( $59 \mathrm{yr} \times 5$ sites $=295$ data points), among which 27 values are missing due to measurements that were not carried out (Thibert and Vincent, 2009). For the sake of consistency, the period of recording analysed is the same as that of Eckert et al. (2011). Expanding the period to include recent years would result in slight changes in the detected trends which might confuse readers. Over this period of recording, the elevation of the glacier surface has dropped by an average 


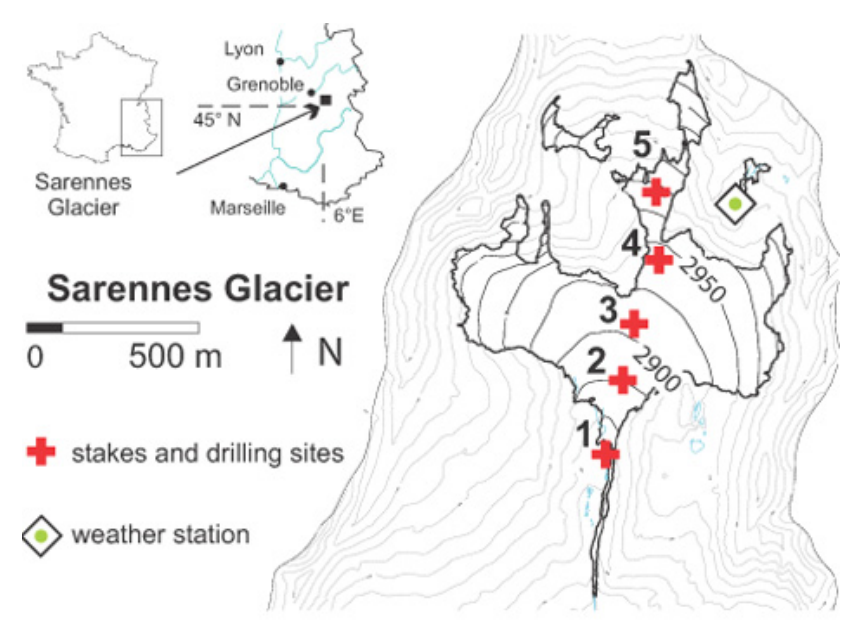

Fig. 1. Location of stakes where balance is measured at Sarennes glacier. Contour lines on the glacier are at $25 \mathrm{~m}$ intervals.

of $36 \mathrm{~m}$ (Thibert et al., 2008), which may well contribute to some forcing in the surface mass balance record. As we did not want to compromise the data by making any assumption about the vertical gradient of the mass balance, no correction has been made for change in elevation, but caution is warranted when analysing time trends in ablation (Sect. 4).

\subsection{Extraction of the seasonal components using variance decomposition}

Extending the precursor work of Lliboutry (1974), different models to extract temporal patterns related to climatic forcing are presented and compared by Eckert et al. (2011). Here, we briefly describe the model that was found to be most suitable for Sarennes. The temporal $\beta_{t}$ signal is first extracted from a linear variance model according to

$b_{i, t}=\alpha_{i}+\beta_{t}$,

where $\alpha_{i}$ is the mean balance recorded at location $i$ over the period of record. Hence, $\beta_{t}$ is the annual deviation from the mean (centred balance). Based on previous work on streamflow (Perrault et al., 2000a, b) and snow avalanche runout elevation modelling (Eckert et al., 2010), $\beta_{t}$ is taken as centred on a linear trend with constant $c_{j}$ and annual rate $d_{j}, \sigma_{j}$ being the standard deviation of the regression residuals and $\tau$ the year preceding a possible rupture in trend and/or variance in each component of the balance (subscript $j=$ before/after the breakpoint):

$\beta_{t}=N\left(c_{j}+d_{j} t, \sigma_{j}^{2}\right)$,

where $N$ denotes a normal distribution centred on $c_{j}+d_{j} t$ with a variance $\left(\sigma_{j}\right)^{2}$. Equation (1) is applied to both measured winter and annual balances $\left(b^{\mathrm{w}}, b^{\mathrm{a}}\right)$. The third component, summer balance $b^{s}$, is available from $b^{\mathrm{s}}=b^{\mathrm{a}}-b^{\mathrm{w}}$
Table 1. Time structure identified by the analysis of variance in the seasonal components of the balance: breakpoint $\tau$, mean (bold face values) and trend in subsequent periods (Eckert et al., 2011).

\begin{tabular}{|c|c|c|c|c|}
\hline \multirow[b]{2}{*}{ Winter balance } & \multirow{2}{*}{$\begin{array}{r}\text { Breakpoint, } \tau \\
1976\end{array}$} & \multicolumn{3}{|c|}{$\begin{array}{l}\left.\text { Mean ( } \mathrm{m} \text { w.e. } \mathrm{yr}^{-1}\right) \\
\text { Trend ( } \mathrm{cm} \text { w.e. } \mathrm{yr}^{-2} \text { ) }\end{array}$} \\
\hline & & $\begin{array}{r}1949-1976 \\
\mathbf{1 . 4 8} \\
-1.3 \\
\end{array}$ & & $\begin{array}{r}1977-2007 \\
\mathbf{1 . 8 8} \\
-0.7 \\
\end{array}$ \\
\hline Summer balance & 1982 & $\begin{array}{r}1949-1982 \\
-\mathbf{2 . 2 6} \\
+2.4\end{array}$ & & $\begin{array}{r}1983-2007 \\
-\mathbf{3 . 2 2} \\
-1.5\end{array}$ \\
\hline Annual balance & 1976-1982 & $\begin{array}{r}\text { 1949-1976 } \\
-\mathbf{0 . 8 0} \\
+1.1\end{array}$ & $\begin{array}{r}1977-1982 \\
\mathbf{0} \\
+1.7\end{array}$ & $\begin{array}{r}\text { 1983-2007 } \\
\mathbf{- 1 . 3 6} \\
-2.2\end{array}$ \\
\hline
\end{tabular}

$\left(b^{\mathrm{s}}<0\right)$. The correlation between the different variables is explicitly taken into account. Equation (2) is applied to the two winter and summer seasonal components instead of to the actually observed couple, allowing two breakpoints in the annual balance time series. Estimation is performed within a Bayesian framework using simulation-based methods for parameter estimation (Brooks, 1998) with evaluation of missing data (Tanner, 1996). Particularly, linear trends and rupture estimated on the unobserved variable $\beta_{t}$, which is itself also estimated, explains why recourse to simulation-based estimation procedures (e.g. Markov chain Monte Carlo methods) is unavoidable.

As detailed in Eckert et al. (2011), the glacier-wide balance $B_{t}$ (annual, winter or summer terms) only differs from $\beta_{t}$ by a constant $\langle B\rangle$ which represents the glacier-wide mean balance over the whole period of record (1949-2007). Yearto-year variations of each mass balance seasonal terms can therefore be indifferently analyzed through $\beta_{t}$ or $B_{t}$ time series. This can be summarised by the following equations:

$B_{t}^{\mathrm{a}}=\beta_{t}^{\mathrm{a}}+\left\langle B^{\mathrm{a}}\right\rangle$ with $\left\langle B^{\mathrm{a}}\right\rangle=-0.97 \mathrm{mw}$.e. $\mathrm{yr}^{-1}$,

$B_{t}^{\mathrm{W}}=\beta_{t}^{\mathrm{w}}+\left\langle B^{\mathrm{w}}\right\rangle$ with $\left\langle B^{\mathrm{w}}\right\rangle=1.69 \mathrm{mw}$.e. $\mathrm{yr}^{-1}$,

and

$B_{t}^{\mathrm{S}}=\beta_{t}^{\mathrm{S}}+\left\langle B^{\mathrm{s}}\right\rangle$ with $\left\langle B^{s}\right\rangle=-2.66 \mathrm{mw}$.e. $\mathrm{yr}^{-1}$,

where upper case letters refer to glacier-wide variables and the superscripts "a", "w", and "s" denote the annual, winter and summer terms, respectively. Signals extracted from such variance decomposition are plotted in Fig. 2.

From the analysis of these extracted temporal signals (Eckert et al., 2011), two marked breaks are identified in winter and summer balance time series in 1976 and 1982, respectively, leading to a relatively complex pattern in the annual mass balance signal with a short high regime period between 1976 and 1982 (Fig. 2a). 
The winter balance extracted from the analysis of variance is plotted in Fig. 2b. The breakpoints identified and the corresponding sub-periods of different means and trends are given in Table 1 . The change in winter mass balance series is a very sharp breakpoint in mean and trends just after 1976: $+0.66 \mathrm{~m}$ w.e. $\mathrm{yr}^{-1}$ separating two periods of 1.48 and $1.88 \mathrm{~m}$ w.e. $\mathrm{yr}^{-1}$ average accumulation, with slightly negative trends in both periods.

The summer balance extracted from the analysis of variance is plotted in Fig. 2c. A breakpoint in mean and variance is identified in 1982, but this one is much smoother than the 1976 winter balance breakpoint. The corresponding periods of different means and trends are given in Table 1. The difference in mean summer balances before and after 1982 is $-0.96 \mathrm{~m}$ w.e. $\mathrm{yr}^{-1}$, between -2.26 and $-3.22 \mathrm{~m}$ w.e. $\mathrm{yr}^{-1}$, respectively.

Regarding correlations between extracted times series, the annual balance is mainly dependent on the summer balance with a correlation coefficient, hereafter denoted as $r$, of 0.89 (Table 2). The winter balance has a lesser effect with a correlation of 0.53 . There is almost no correlation between winter and summer balances. Trends and breakpoints account for 20-30\% of the variance of the different components of the balance, the rest being made-up of random interannual fluctuations. With respect to how trends are related to each other over the 6 decades, $83 \%$ of the trends in the annual balance are related to the summer balance trends, and there is almost no correlation between trends for the winter balance and the annual balance (Table 3).

\subsection{Local meteorological variables}

To infer potential drivers, we relate the extracted annual and low-frequency signals to annual and low-frequency signals in meteorological data of different scale relevance. In the vicinity of Sarennes glacier, an automatic weather station operating at $3000 \mathrm{~m}$ a.s.l. since 2004 records $30 \mathrm{~min}$ averages of air temperatures and relative humidity as well as wind speed and direction. To cover the entire mass balance record period, homogenised daily temperatures measured at the meteorological station (Météo-France) in Lyon (200 m a.s.l.) are available. Located $120 \mathrm{~km}$ from Sarennes in the Rhone Valley, the Lyon meteorological series can reasonably be used as temperature fluctuations are well correlated over large areas (Böhm et al., 2001). More specifically, Lyon summer temperatures correlate well with other meteorological stations closer to Sarennes on shorter records (Vincent and Vallon, 1997).

Over the common recording period, mean daily temperatures at the glacier's automatic weather station correlate well with Lyon ( $r=0.85$; Fig. 3 ), especially between April and October $(r=0.89)$. The observed vertical lapse rate during the ablation period is $6.25^{\circ} \mathrm{C} \mathrm{km}^{-1}$, just below the freetroposphere wet adiabatic vertical gradient of $6.5^{\circ} \mathrm{C} \mathrm{km}^{-1}$. It drops to $4.9^{\circ} \mathrm{C} \mathrm{km}^{-1}$ in winter with a poor correlation
( $r=0.44)$ between both weather stations. Considering these seasonal gradients to be constant along the mass balance record is supported by results of the 44-yr-reanalysis of climate in the French Alps by Durand et al. (2009a). Lyon temperatures (May to October annual means) are plotted in Fig. 4a over the 1949-2007 period. Analysis with a breakpoint model similar to the one used for Sarennes highlights a gradual change in the middle of the 1970s $(1974 \pm 5 \mathrm{yr})$ followed by a strong and continuous increase $\left(+1.32^{\circ} \mathrm{C}\right)$ since 1982. Increases were greatest in August and May $(+1.85$ and $\left.+1.66^{\circ} \mathrm{C}\right)$ and smallest in September $\left(+0.58^{\circ} \mathrm{C}\right)$. In winter months, the temperature has risen by about $1{ }^{\circ} \mathrm{C}$. This main low-frequency pattern in summer temperatures is consistent with the results of a broad range of studies which show marked warming at high elevations since the middle of the 1970s, notably in the Alpine space (e.g. Beniston et al., 1997).

To relate precipitation on the glacier to the valley station, the nearest $(6 \mathrm{~km})$ long (since 1907$)$ daily precipitation record is the meteorological station (Météo France) located at Besse en Oisans at an elevation of $1400 \mathrm{~m}$ a.s.l. Besse precipitations correlate poorly with Lyon but very well $(r=0.97)$ with Bourg d'Oisans $12 \mathrm{~km}$ away (Vincent and Vallon, 1997). Analysing the series with a breakpoint model identifies a marked change in 1976, with a strong shift separating two periods with a decreasing trend (Fig. 4b). This sharp breakpoint in winter precipitation is more regional than the 1982 one in summer temperature signal. Indeed, it is significant for snowfalls and weather series in the northern French Alps (Durand et al., 2009a, b) but is not obvious at the larger scale of the entire European Alps (Quadrelli et al., 2001).

\subsection{Large-scale atmospheric meteorological variables}

\subsubsection{North Atlantic Oscillation}

Although it is well established that regional climate drives the changes in the different seasonal mass balance terms, how they are controlled by larger-scale synoptic variables remains a more open question. A difficulty is that, among the several large-scale or synoptic indices available, it is hard to identify which ones accurately summarise atmospheric fluctuations that can drive glacier mass balance. For example, the Atlantic Multidecadal Oscillation (AMO) occurring in the North Atlantic Ocean and reflecting sea surface temperature (SST) variability has been reported to be well correlated to glacier mass balance in Switzerland (Huss et al., 2010). This is understandable since the AMO is physically based on temperature and, despite being an oceanic oscillation mode, positive AMO phases are effectively related to positive near-surface air temperature anomalies in continental Europe. Hence, as reported by Huss et al. (2010), AMO index and homogenised instrumental air temperature records for the Alps correlate well. It is therefore reasonable that 
Table 2. Correlation matrix between the different time series. Bold face values are significant non-zero correlations at the $95 \%$ confidence level. Besse precipitations are winter cumulative precipitations between Sarennes field visits. Lyon temperatures are May-October daily means.

\begin{tabular}{|c|c|c|c|c|c|c|c|c|}
\hline Variables & $\begin{array}{l}\text { Annual } \\
\text { balance }\end{array}$ & $\begin{array}{l}\text { Summer } \\
\text { balance }\end{array}$ & $\begin{array}{l}\text { Winter } \\
\text { balance }\end{array}$ & $\begin{array}{r}\text { Besse } \\
\text { precipitation }\end{array}$ & $\begin{array}{r}\text { Lyon } \\
\text { temperature }\end{array}$ & $\begin{array}{r}\text { DJF } \\
\mathrm{NAO}\end{array}$ & $\begin{array}{r}\text { NDJFMA } \\
\text { NAO }\end{array}$ & $\begin{array}{r}\text { Annual } \\
\text { NAO }\end{array}$ \\
\hline Annual balance & 1 & 0.89 & 0.53 & 0.6 & -0.64 & -0.25 & -0.25 & -0.1 \\
\hline Summer balance & & 1 & 0.08 & 0.27 & -0.76 & -0.33 & -0.32 & -0.11 \\
\hline Winter balance & & & 1 & 0.81 & 0.02 & 0.08 & 0.06 & -0.02 \\
\hline Besse precipitation & & & & 1 & -0.08 & -0.03 & -0.03 & -0.03 \\
\hline Lyon temperature & & & & & 1 & 0.41 & 0.37 & 0.02 \\
\hline DJF NAO & & & & & & 1 & 0.93 & 0.67 \\
\hline NDJFMA NAO & & & & & & & 1 & 0.75 \\
\hline Annual NAO & & & & & & & & $\mathbf{1}$ \\
\hline
\end{tabular}

Table 3. Correlation matrix between trends in the different time series. Bold face values are significant non-zero correlations at the $95 \%$ confidence level. All trends are provided by the variance decomposition model of Eq. (2), apart from trends in NAO anomalies resulting from the 7-yr triangular moving averages. Besse precipitations are winter cumulative precipitations between Sarennes field visits. Lyon temperatures are May-October daily means.

\begin{tabular}{lrrrrrrrr}
\hline Variables & $\begin{array}{r}\text { Annual } \\
\text { balance }\end{array}$ & $\begin{array}{r}\text { Summer } \\
\text { balance }\end{array}$ & $\begin{array}{r}\text { Winter } \\
\text { balance }\end{array}$ & $\begin{array}{r}\text { Besse } \\
\text { precipitation }\end{array}$ & $\begin{array}{r}\text { Lyon } \\
\text { temperature }\end{array}$ & $\begin{array}{r}\text { DJF } \\
\text { NAO }\end{array}$ & $\begin{array}{r}\text { NDJFMA } \\
\text { NAO }\end{array}$ & $\begin{array}{r}\text { Annual } \\
\text { NAO }\end{array}$ \\
\hline Annual balance & $\mathbf{1}$ & $\mathbf{0 . 9 1}$ & -0.21 & $\mathbf{0 . 3 2}$ & $-\mathbf{0 . 8 4}$ & $-\mathbf{0 . 4 4}$ & $-\mathbf{0 . 3 9}$ & 0.05 \\
Summer balance & & $\mathbf{1}$ & $-\mathbf{0 . 5 9}$ & -0.08 & $-\mathbf{0 . 9 4}$ & $-\mathbf{0 . 5 7}$ & $-\mathbf{0 . 5 1}$ & -0.04 \\
Winter balance & & & $\mathbf{1}$ & $\mathbf{0 . 8 1}$ & $\mathbf{0 . 5 9}$ & $\mathbf{0 . 5 0}$ & $\mathbf{0 . 4 5}$ & 0.20 \\
Besse precipitation & & & & $\mathbf{1}$ & 0.02 & $\mathbf{0 . 3 5}$ & $\mathbf{0 . 2 8}$ & $\mathbf{0 . 3 3}$ \\
Lyon temperature & & & & & & $\mathbf{0 . 4 5}$ & $\mathbf{0 . 4 2}$ & -0.09 \\
DJF NAO & & & & & & $\mathbf{1}$ & $\mathbf{0 . 9 3}$ & $\mathbf{0 . 6 7}$ \\
NDJFMA NAO & & & & & & & $\mathbf{1}$ & $\mathbf{0 . 7 5}$ \\
Annual NAO & & & & & & & & $\mathbf{1}$ \\
\hline
\end{tabular}

glacier mass balance should correlate well with AMO since glacier summer balances are closely related to atmospheric temperature and make the greatest contribution to annual mass balance variance.

In the North Atlantic and Alpine space, another commonly used large-scale driver is the NAO, which is an atmospheric variability mode known to have a great influence, especially on winter climate (e.g. Quadrelli et al., 2001). Therefore, a relationship should exist between NAO and the winter mass balance of Scandinavian glaciers, glaciers at the eastern boundary of the North Atlantic Ocean and Alpine glaciers. However, the link to glacier annual mass balance is expected to be weaker for glaciers in continental regions such as the European Alps since winter accumulation generally has a smaller, more tenuous influence on annual balances for glaciers in these regions. Significant relationships are indeed reported for annual mass balance in Scandinavian glaciers and Svalbard (Pohjola and Rogers, 1997; Washington et al., 2000; Fealy and Sweeney, 2005), with substantial differences between northern and southern Scandinavia (Marzeion and Nesje, 2012). For Alpine glaciers, the reported correlation is weak (Reichert et al., 2001; Six et al., 2001) and decreases as one goes from the eastern to the southwestern
Alps (Marzeion and Nesje, 2012). Here, analysing the long record of Sarennes seasonal balances can bring new information about how the link between the NAO and annual mass balance may divide between winter and summer mass balance components at the specific location of Sarennes in the deep northern-southern French Alps.

For this study, we used the classical monthly standardised series from Jones et al. (1997) complemented by Osborn (2006) for recent years. Three different cumulated anomalies have been considered: December to February (DJF, 3 months), November to March (NDJFBM, 6 months), and October to September (annual, 12 months).

\subsubsection{Data process}

Smoothing NAO anomalies is a recognised way of detecting similar patterns (i.e. trends of the low-frequency signals) in local series and NAO data because, at the annual scale, NAO series are highly variable, which compromises correlation. NAO anomalies smoothed over several years have therefore been intensively used in Switzerland (Beniston, 2005; Beniston and Jungo, 2002; Beniston et al., 1997; Scherrer and Appenzeller, 2006) to discuss and explain recent changes 


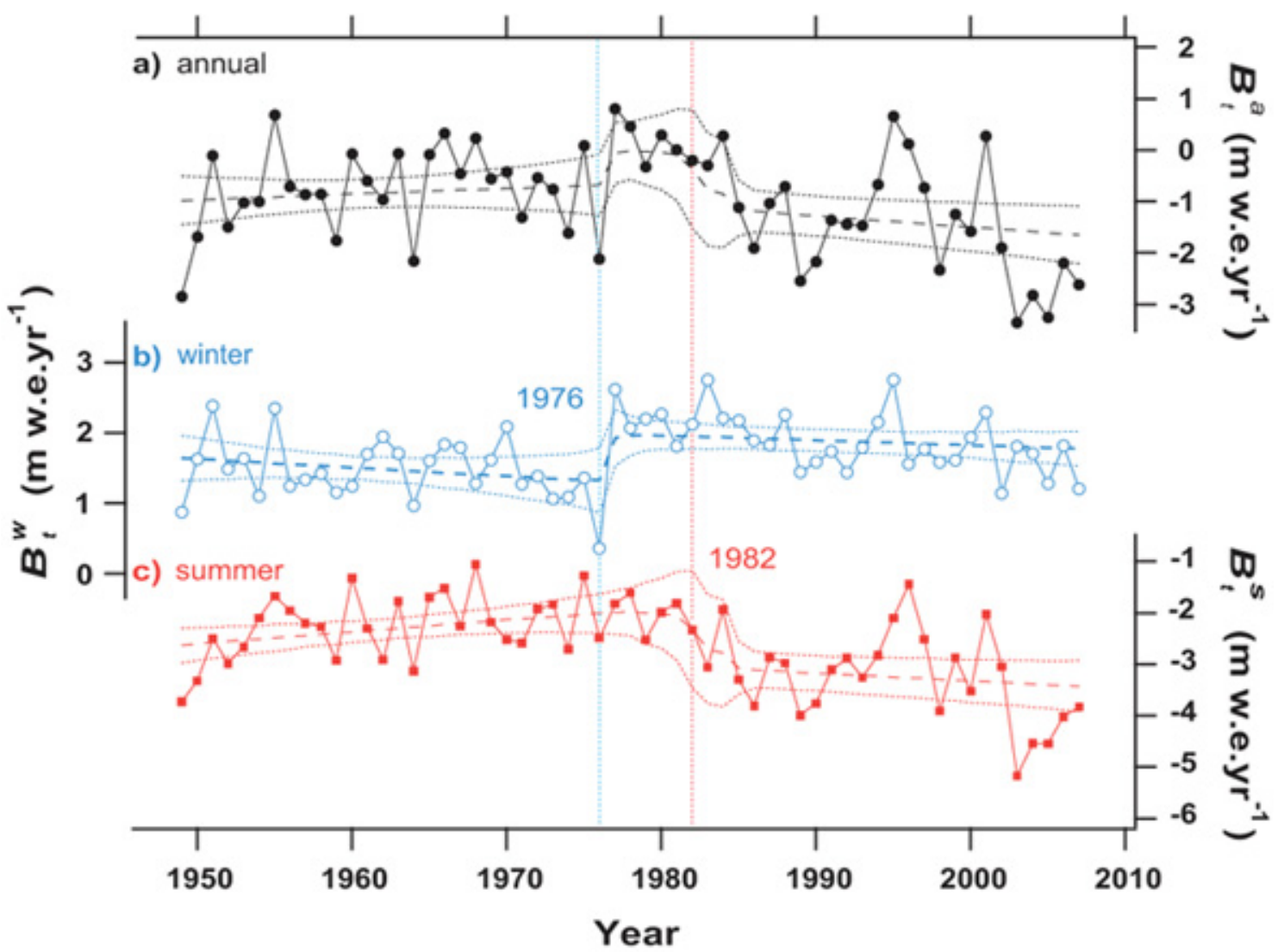

Fig. 2. (a) Annual, (b) winter, and (c) summer glacier-wide balances at Sarennes extracted from the analysis of variance. Dashed lines are trends and dotted lines are $95 \%$ credible intervals for the trends. The blue and red vertical dotted lines highlight the breakpoints in winter and summer balances in 1976 and 1982, respectively.

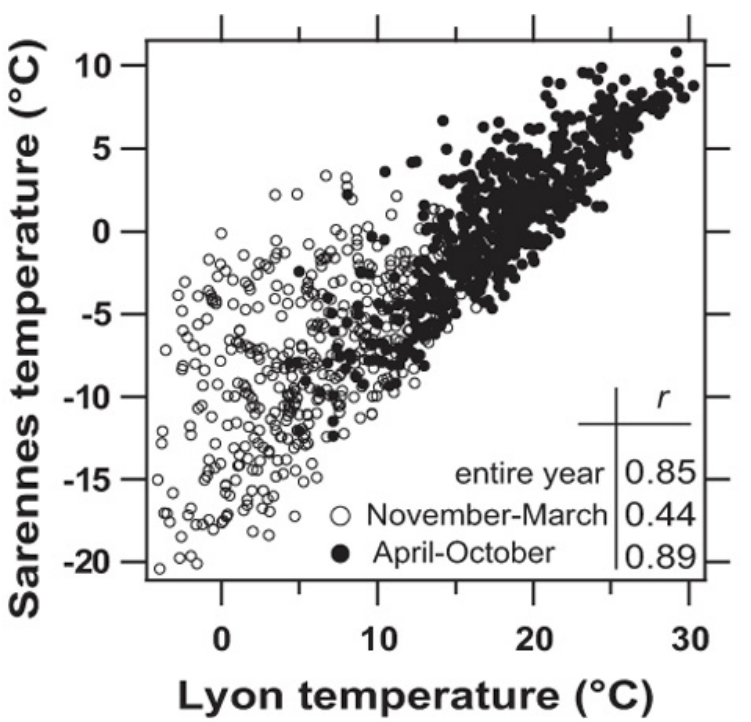

Fig. 3. Correlation between daily temperatures measured at Sarennes $(3070 \mathrm{~m})$ and Lyon-Bron (200 ma.s.1.) recorded over 2004-2007. in weather patterns and snow pack characteristics at high altitudes. For the French Alpine area space, smoothed NAO anomalies have been used by Durand et al. (2009a,b) in a similar way and by Six et al. (2001) to analyse several glacier mass balance data including Sarennes, but over a much shorter time period (1966-1998) and only for annual balance. Here, having sixty years of data on the three components of mass balance as well as their underlying trends, more significant correlations can be searched as well as how the different components respond to the large-scale forcing, both for the annual values and low-frequency signals.

However, the different NAO series cannot be statistically analysed in the same way as the Sarennes data and local covariates. The first reason is that there is no need for variance decomposition between space and time. The second reason is because there are two marked breakpoints on the trends of the low-frequency of the NAO time series (around 1970 and 1990) as opposed to only one over the period of record at Sarennes. Furthermore, since a smoothed signal should not be correlated with a non-smoothed one, relationships are only sought between smoothed mass balance signals extracted using ANOVA with smoothed NAO series, in order 


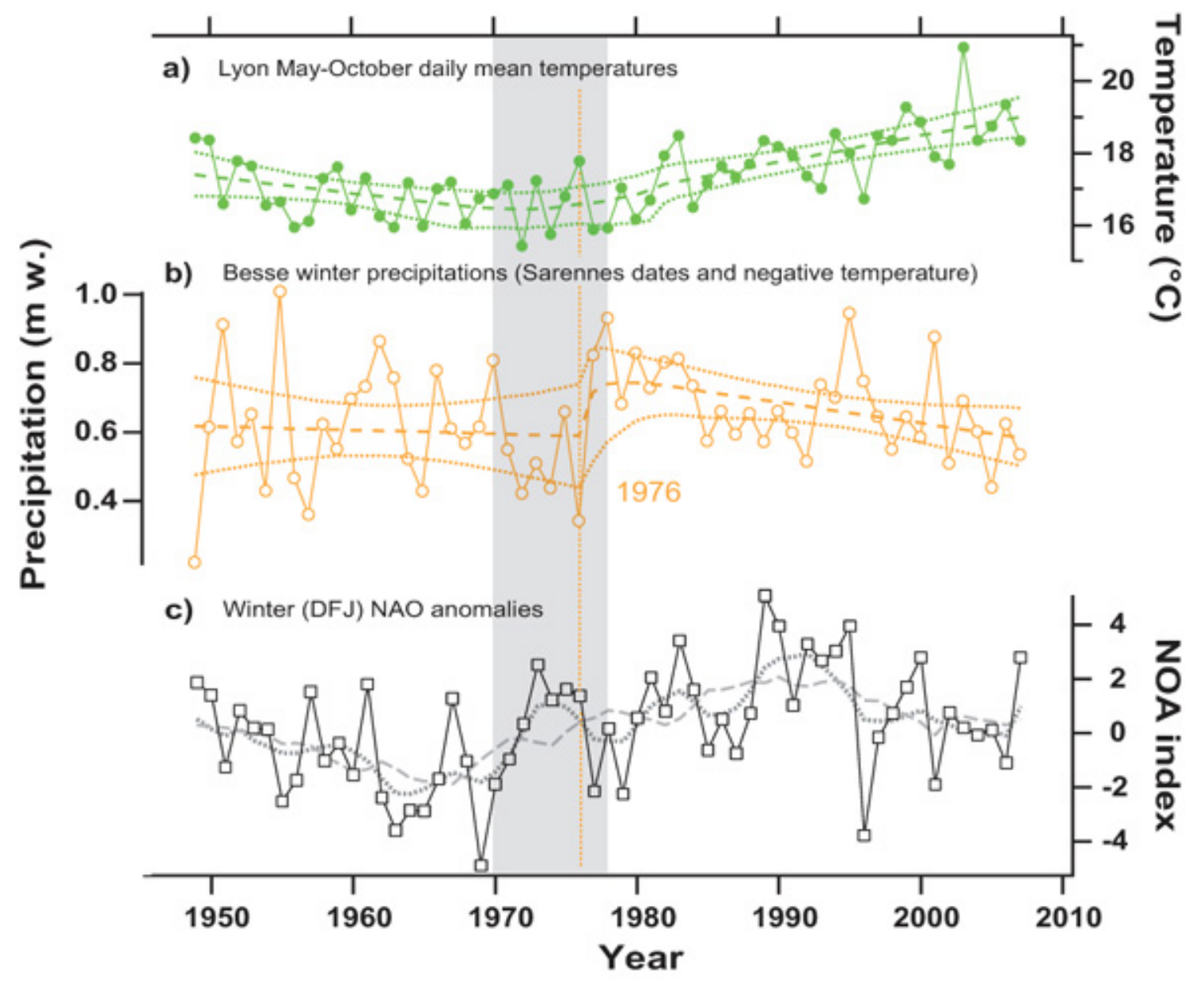

Fig. 4. (a) May to October daily mean temperatures at Lyon-Bron (200 m a.s.1.) weather station with trends (dashed line) and $95 \%$ credible intervals (dotted line) for the trends; (b) winter precipitation amount recorded at Besse (1400 m a.s.1.) weather station according to Sarennes measurement dates and negative temperature on the glacier, with trends (dashed line) and $95 \%$ credible intervals (dotted line) for the trends; (c) December to January (DFJ) NAO anomalies (black line and squares), 5-yr smoothed data (grey dotted line), 11-yr smoothed (grey dashed line). The time range in grey is the gradual change ( $1974 \pm 4 \mathrm{yr})$ in the temperature signal.

to highlight possible convergent low-frequency patterns (as is done for temperature and precipitation trends). This brings out links between smoothed glaciological data and underlying trends in temperature, precipitation, mass balance and $\mathrm{NAO}$ - which are difficult to discern at the annual level.

Considering the correlation between NOA anomalies and the different mass balance components as a function of the level of smoothing shows the frequencies at which seasonal mass balance fluctuations correlate most closely with the NAO signal. Different filters and time windows have been investigated. Figure 5 presents detailed results for DJF NAO anomalies processed with the retained triangular filters (i.e. weighted moving averages with weights decreasing linearly). It confirms that it is not at the annual scale that the different mass balance components are best correlated with the NAO signal. The very low correlations between annual anomalies and the different mass balance components slowly increase with the NAO filtering window size. Maximum correlation is reached with filtering windows of between 5 and $15 \mathrm{yr}$, depending on which variable is being considered, i.e. mean frequencies with respect to the duration of the whole investigated period. The NAO breakpoints are clearly visible in Fig. 4c for DJF anomalies after smoothing of the data with an 11-yr moving average filter to separate interannual variability from the structured signal. This is consistent with the analysis of Fealy and Sweeney (2005). Furthermore, a 5-yr moving average filter characterises the well-known 7-10 yr periodicity of the NAO signal, which is far from obvious in Sarennes series.

Correlations are, for all variables, systematically higher in absolute values and more significant between low-frequency patterns provided by Eq. (2) and smoothed NAO signals than between the annual variables themselves and smoothed NAO signals. This result shows the advantages and limitations of 

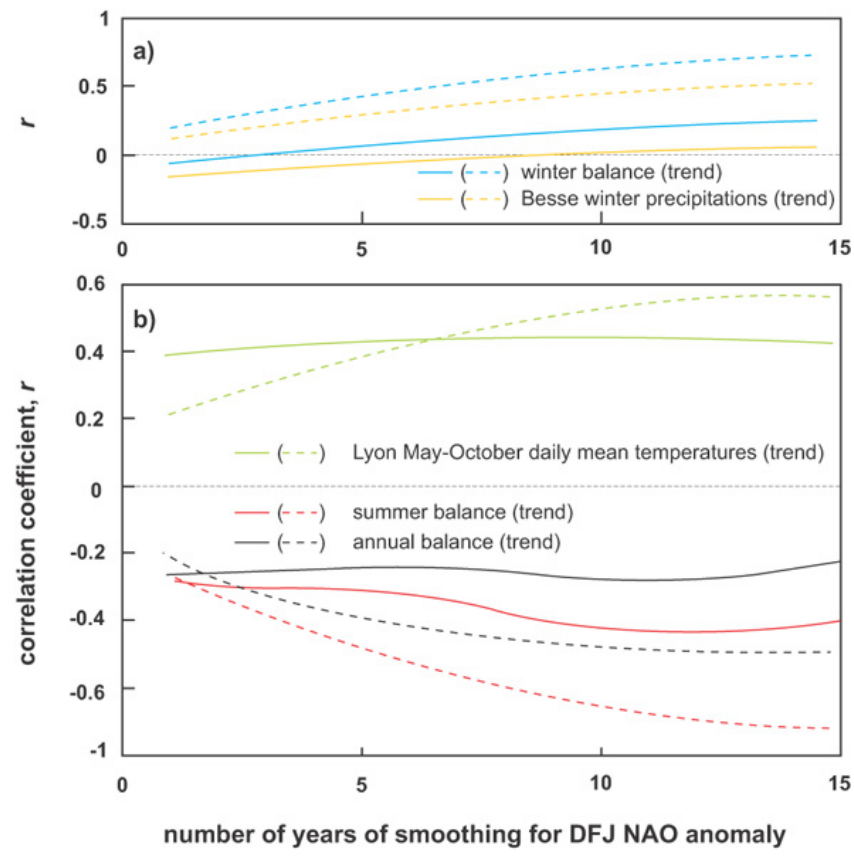

Fig. 5. Correlation between NAO winter (DFJ) anomalies and local variables as a function of the level of smoothing. (a) Winter variables: winter mass balance and Besse winter precipitations; (b) summer/annual variables: summer and annual mass balances, and Lyon-Bron May to October mean temperatures. Continuous and dashed lines refer to annual and trends of local variables, respectively.

comparing smoothed data and/or trends instead of the variables themselves. On the one hand, it points out similarly structured changes, e.g. similar changes in local variables and large-scale patterns. On the other hand, the problem of comparing two smoothed signals is that, for large smoothing windows, significant correlations will nearly always be obtained as soon as the data are not entirely random. To limit this bias, in the rest of the paper, we use the lowest level of smoothing necessary to obtain optimum correlation with Sarennes data, i.e. a 7-yr time window (current value $\pm 3 \mathrm{yr}$ ) for the various NAO anomalies considered.

Regarding the significance of the correlations inferred for smoothed series, autocorrelation structure should be taken into account when computing confidence intervals and testing significance. In practice, this autocorrelation structure is generally not known even for direct measurements, and empirical estimates for the correlation coefficient are nevertheless often computed. The same approach was therefore used for correlations between trends, even if the autocorrelation between smoothed series is by definition partially known and stronger than between raw annual values. Hence, the significance levels provided in Table 3 should be considered as "optimistic" thresholds.

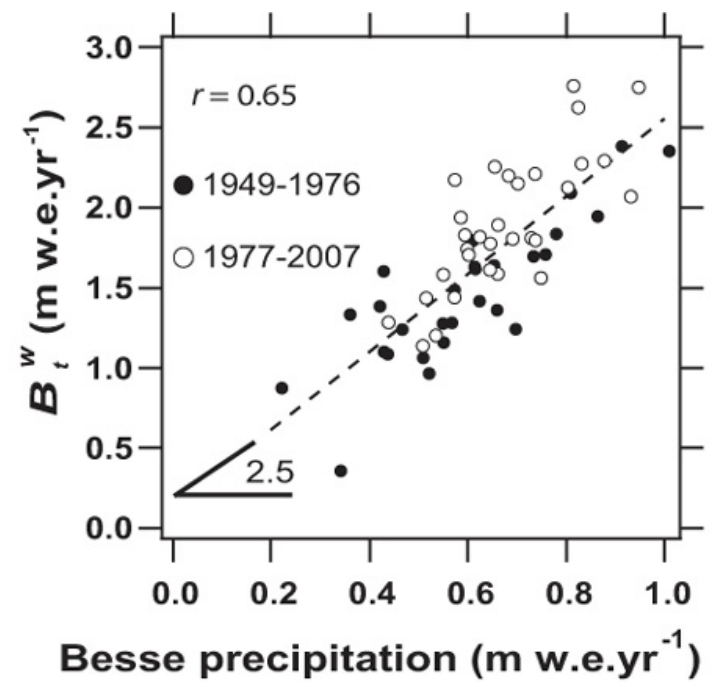

Fig. 6. Glacier-wide winter balance at Sarennes as a function of precipitation recorded at Besse weather station (only for days with precipitation and a temperature below $0{ }^{\circ} \mathrm{C}$ at Sarennes).

\section{Winter mass balance}

\subsection{Link with local covariates}

For each year of the period of record, the glacier-wide winter balance $B_{t}^{\mathrm{w}}$ obtained from the analysis of variance has been plotted against precipitations recorded at Besse weather station over the same period (end of ablation season year $n-1$, measurement date winter balance year $n$; Fig. 6). Only days of solid precipitation with temperatures below $1{ }^{\circ} \mathrm{C}$ are concerned, rain being assumed to run off the glacier and not to contribute to mass balance when the temperature is higher. Temperatures on the glacier are calculated from the Lyon weather station with a $4.9^{\circ} \mathrm{C} \mathrm{km}^{-1}$ mean altitudinal gradient for the winter season. Varying the rain-snow divide by $1-2{ }^{\circ} \mathrm{C}$, does not significantly change the results.

Figures $2 \mathrm{~b}$ and $4 \mathrm{~b}$ show the 1976 breakpoint in both Sarennes winter balance and Besse precipitation. Furthermore, Besse and Sarennes winter data correlate well $(r=$ 0.81 ; Table 2). The same correlation is observed in trends provided by Eq. (2) in Table 3. Coherence in trends and breakpoints between Besse and Sarennes indicate a similar behaviour in terms of time-structured interannual patterns.

With a fixed date calculation (October-May), correlation drops from $r=0.81$ to $r=0.73$, close to the 0.75 value reported by Vincent and Vallon (1997) over the shorter period 1949-1994. Examining monthly precipitations at Besse in more detail shows that precipitation changes since 1976 are mainly due to increases in early winter (October) and late winter (March, April and May). On the other hand, no trend or rupture is observed in precipitation in the middle of winter. 
Analyzing Lyon temperatures reveals that winter (OctoberMay) temperatures increased by $1.09^{\circ} \mathrm{C}$, with the highest increases recorded in May, October and March $\left(+1.67^{\circ} \mathrm{C}\right.$, $+1.48^{\circ} \mathrm{C}$ and $+1.23^{\circ} \mathrm{C}$, respectively). Warming in November to February is only $+0.8^{\circ} \mathrm{C}$. Increased precipitation observed at Sarennes since 1976 could therefore be related to milder temperature conditions in winter, particularly in early and late winter. More precipitation associated with higher temperature and decreasing snow cover in early summer is documented by Durand et al. (2009a) for the French Alps, and even at the larger scale of the mid latitudes (McCabe and Wolock, 2010).

Regarding precipitation and accumulation, Fig. 6 shows the ratio between winter mass balance at Sarennes and Besse winter precipitation. The ratio of 2.5 confirms the large difference between the amount of valley precipitation and winter accumulation at high elevation. Considering that this ratio may differ considerably from one glacier to another, this value is singularly very close to that of 2-3 reported between Besse and Saint-Sorlin glacier (5 km from Sarennes) for the same altitude range (Vincent, 2002). Ratios in the range 2.32.6 are also indicated for Glacier Blanc (Rabatel et al., 2008), with a comparable altitude difference $(1600 \mathrm{~m})$ between the glacier and the closest downhill weather station. This ratio corresponds to a mean altitudinal gradient of annual precipitation of $840 \mathrm{~mm}(1000 \mathrm{~m})^{-1}$ which is 4 times higher than large-scale values of $200 \mathrm{~mm}(1000 \mathrm{~m})^{-1}$, reported by Durand et al. (2009a) for south and central Alps. This indicates that specific accumulation processes at the glacier scale supplement the classical orographic effect. A possible explanation already reported by Vincent (2002) is that wind drifts on surrounding nonglacial slopes and avalanches may capture snow over a larger area than the glacier itself. Since the above processes are strongly dependent on local topography, the consistency of the precipitation ratios found for the nearby glaciers is singular. Hence, for all these glaciers, the classical orographic gradient cannot be used solely to calculate winter accumulation at the scale of a high altitude englacial basin.

\subsection{Link to NAO anomalies}

There is almost no correlation between winter balance and NAO anomalies (Table 2), for 3-month, 6-month or annual values. Results are very similar for Besse precipitations. This is reasonable since Besse correlates well with the Sarennes winter balance. These results are consistent with observations by Durand et al. (2009b), indicating a relatively surprising almost absence of correlation between winter NAO anomalies and snow cover data in the French Alps. Therefore, our results at Sarennes seem to contradict the significant negative correlation reported for snow depth (Benniston, 1997) and cumulative winter snow in Switzerland (Scherrer and Appenzeller, 2006). Marzeion and Nesje (2012) indicate weak correlations between the NAO and modelled winter balance for glaciers in the Alps but highlight a spatial structure with some contrast: negative weak correlations are reported in the Western Alps. In contrast, positive correlations are found for glaciers in the Eastern Alps where winter balances are associated with NAO deviations as in Scandinavian glaciers, although more smoothly. This contrast tends to confirm our finding that, at some places, at least in the internal Alps, year-to-year winter precipitation can be somewhat disconnected from NAO variations. A possible explanation is that in the Grande Rousses range, Sarennes and Besse weather station are located between internal dry valleys where western (Atlantic) low-pressure systems only produce mitigated precipitations. Moreover, the Ecrins range to the south and Thabor and Queyras ranges to the east protect Sarennes and Besse area from the Genoa low-pressure system which develops to the south of the Alps and causes precipitation coming from the south and the east.

Hence, precipitations and winter balance at Sarennes are poorly connected to the synoptic signal summarised in the NAO index. This explains why the temporal pattern detected in the Sarennes winter balance and high-altitude precipitations (strong breakpoint in 1976) have an almost limited regional significance. Indeed, if it is reported on other glaciers in the French Alps (Vincent, 2002), its intensity decreases slowly from southern to northern French Alps. No specific trend or rupture is reported in glacier winter balances in the central and eastern Swiss Alps, like Silvretta and Clariden glaciers (Müller and Kappenberger, 1991; Vincent et al., 2004; Huss and Bauder, 2009). Closer to Sarennes, only Aletsch glacier (Valis region) still shows a synchronous breakpoint in winter balance around 1974-1976 (Huss and Bauder, 2009), but this one is less sharp than observed for the French glaciers.

Our approach that extracts the low-frequency pattern in the various components of the Sarennes data and covariates also makes it possible to compare trends in precipitations in Besse and accumulation at Sarennes provided by Eq. (2) with the retained 7-yr smoothed NAO anomalies (Table 3). They are significantly correlated (Fig. 7a) with the relevant signal concentrated in the DJF series for which the correlation is the highest. The positive sign of the significant correlation is nevertheless surprising, since one would intuitively expect high snow accumulations to be associated with negative NAO anomalies, as exposed above. Following the analyses of Marzeion and Nesje (2012), this would suggest Sarennes to be more connected with the eastern part of the Alps where winter balances positively correlate with NAO, but this would only concern long-term trends.

However, some methodological biases cannot be totally excluded. With respect to the limitation when it comes to comparing smoothed signals as highlighted in Sect. 2.4.1, this result must be interpreted with care since correlation is not equivalent to causality. Here, the trend in accumulation is mostly downward over the study period as a whole, but with a strong shift around 1977. In contrast, the DFJ NAO anomaly decreased up to 1970 and again after 1990, i.e. over 
a) Winter mass balance $r=0.5$

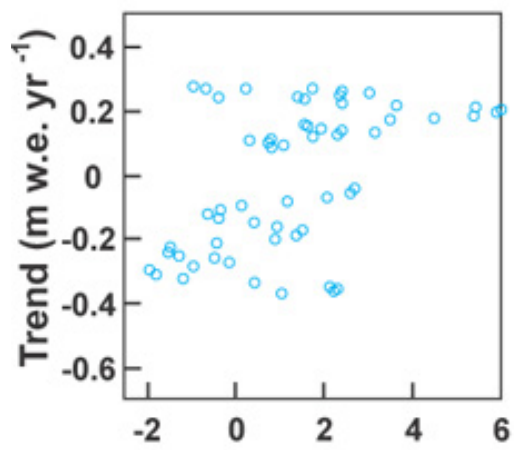

Trend in DFJ NAO anomaly b) Summer mass balance $r=-0.57$

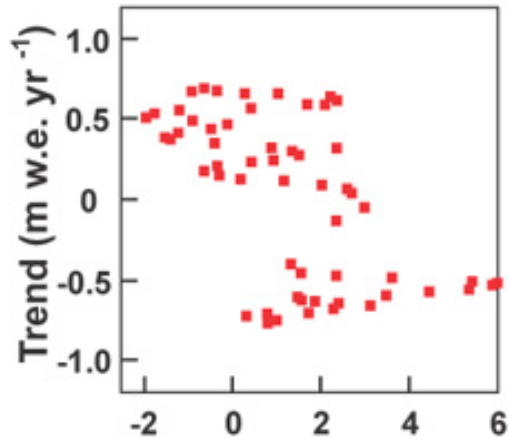

Trend in DFJ NAO anomaly c) Annual mass balance $r=-0.44$

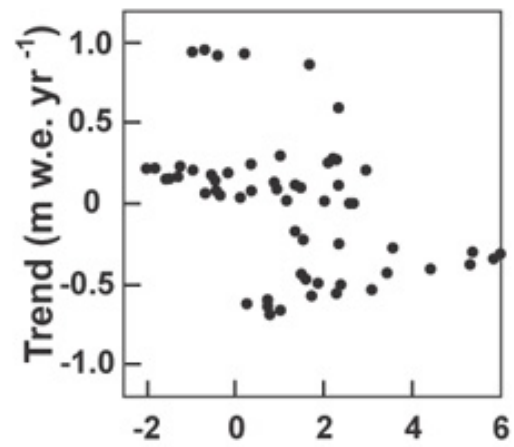

Trend in DFJ NAO anomaly

Fig. 7. Correlation between trends in NAO anomalies (7-yr smoothed DFJ) and trends in the three components of Sarennes winter (a), summer (b), and annual (c) mass balance provided by the variance analysis.

about two thirds of the studied period. The positive correlation between the trends of the low-frequency signals in accumulation and NAO anomalies could therefore only represent the predominance of negative trends in both time series, and it does not necessarily imply that long-term changes in NAO anomalies really control long-term changes in winter balance in Sarennes.

\section{Summer balance}

Regarding snow and ice melt jointly, ablation has increased by $1.1 \mathrm{~m}$ w.e. $\mathrm{yr}^{-1}(+43 \%)$ since 1982 (Table 4$)$. This is due to both longer and more intense ablation. The duration of snow and ice ablation rose from 115 to 139 days (+24 days, i.e. $+19 \%$ ) between the two periods $1949-1982$ and 19832007. Ablation starts 13 days earlier in spring (May) and continues for 11 days longer in autumn (October). In parallel, ablation rates rose by $0.44 \mathrm{~cm}$ w.e. day ${ }^{-1}(+22 \%)$ over the last $25 \mathrm{yr}$ of the record. Therefore, the rise is due to both intensification $(53 \%)$ and longer ablation $(47 \%)$. However, analysing how snow and ice contribute separately to these ablation changes yields to more nuanced figures as discussed in the following Sects. 4.1 and 4.2.

\subsection{Snow ablation}

\subsubsection{Intensity and duration}

Distinction can be made between the rates and durations of snow and ice ablation by virtue of very extensive mass balance observations made during the melting season which make it possible to establish the snow-to-ice transition date within a few days at each measurement location. In practice, temporal interpolations between visit dates are used to determine the date of snow-to-ice transition, which we estimate to be correct within a few days. This analysis requires con-
Table 4. Amount, duration and rate for indistinct snow and ice ablations at Sarennes over the whole period of record and before and after the breakpoint identified by the analysis of variance. Bold face values are variations after the 1982 breakpoint identified in the summer balance time series.

\begin{tabular}{rrrr}
\hline & \multicolumn{3}{c}{ Total ablation (snow and ice) } \\
\hline & $\begin{array}{r}\text { Mean } \\
\left(\text { m w.e. } \text { yr }^{-1}\right)\end{array}$ & $\begin{array}{r}\text { Duration } \\
(\text { days })\end{array}$ & $\begin{array}{r}\text { Rate } \\
\left(\text { cm w.e. day }^{-1}\right)\end{array}$ \\
\hline $1949-2007$ & 2.55 & 125 & 2.03 \\
$1949-1982$ & 2.08 & 115 & 1.84 \\
$1983-2007$ & 3.18 & 139 & 2.28 \\
& $(+\mathbf{1 . 1 0})$ & $(+\mathbf{2 4})$ & $(+\mathbf{0 . 4 4})$ \\
\hline
\end{tabular}

sidering hereafter point mass balance recorded at a single stake rather than an average for the overall glacier. As explained by Thibert and Vincent (2009), because the centred summer balance, $\beta_{t}^{\mathrm{s}}$, is the common annual response at all measurement points, choosing the location that holds most of the information is choosing the one that correlates the best with the centred summer balance $\beta_{t}^{\mathrm{s}}$, or identically, with the glacier-wide summer balance $B_{t}^{\mathrm{S}}$ (Sect. 2.2). We therefore select stake 4 , which correlates best with $\beta_{t}^{\mathrm{s}}$ and explains the main part of the variance $(r=0.97)$ of the centred summer balance (Fig. 8).

Between the two periods highlighted by the variance decomposition model, snow ablation increased from $1.42 \mathrm{~m}$ w.e. $\mathrm{yr}^{-1}$ to $1.70 \mathrm{~m}$ w.e. $\mathrm{yr}^{-1}$ at stake no. 4 (Table 5). Its duration did not change between the two periods (mean 86 days). Ablation duration at stake 4 for snow is shown in Fig. 9. Snow ablation both starts and ends 13 days earlier. The $0.28 \mathrm{~m}$ w.e. $\mathrm{yr}^{-1}$ snow ablation rise since the $80 \mathrm{~s}$ is therefore exclusively due to intensification. Snow ablation rates have indeed risen from $1.77 \mathrm{~cm}$ w.e. day ${ }^{-1}$ before 1982 to 
Table 5. Amount, duration and rate for snow and ice ablation at Sarennes over the whole period of record as well as before and after the breakpoint identified by the analysis of variance. Bold face values are differences after the 1982 breakpoint identified in the summer balance time series.

\begin{tabular}{|c|c|c|c|c|c|c|}
\hline & \multicolumn{3}{|c|}{ Snow ablation } & \multicolumn{3}{|c|}{ Ice ablation } \\
\hline & $\begin{array}{r}\text { Mean } \\
\left(\mathrm{m} \text { w.e. } \mathrm{yr}^{-1}\right)\end{array}$ & $\begin{array}{r}\text { Duration } \\
\text { (days) }\end{array}$ & $\begin{array}{r}\text { Rate } \\
\left(\mathrm{cm} \mathrm{w.e.} \mathrm{day}^{-1}\right)\end{array}$ & $\begin{array}{r}\text { Mean } \\
\left(\mathrm{m} \text { w.e. } \mathrm{yr}^{-1} \text { ) }\right.\end{array}$ & $\begin{array}{r}\text { Duration } \\
\text { (days) }\end{array}$ & $\begin{array}{r}\text { Rate } \\
\left(\mathrm{cm} \text { w.e. day }{ }^{-1}\right)\end{array}$ \\
\hline 1949-2007 & 1.54 & 86 & 1.88 & 1.01 & 39 & 2.59 \\
\hline 1949-1982 & 1.42 & 86 & 1.77 & 1.07 & 29 & 2.50 \\
\hline \multirow[t]{2}{*}{ 1983-2007 } & 1.70 & 86 & 2.04 & 1.80 & 53 & 2.75 \\
\hline & $(+\mathbf{0 . 2 8})$ & (0) & $(+0.27)$ & $(+\mathbf{0 . 7 3})$ & $(+24)$ & $(+\mathbf{0 . 2 5})$ \\
\hline
\end{tabular}

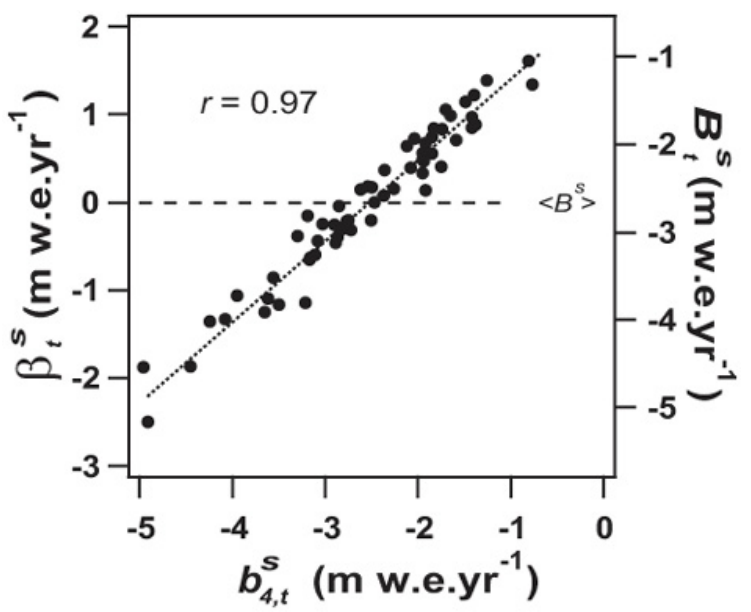

Fig. 8. Selection of a single stake to represent the overall summer centred balance, $\beta_{t}^{\mathrm{s}}$, or glacier-wide summer balance, $B_{t}^{\mathrm{s}}$. Stake 4 is the best estimator and the summer balance, $b_{4, t}^{\mathrm{s}}$, recorded at this location is highly correlated to the centred summer balance. Over the period of record, $\left\langle B^{\mathrm{s}}\right\rangle$ is $-2.66 \mathrm{~m}$ w.e. $\mathrm{yr}^{-1}$.

$2.04 \mathrm{~cm}$ w.e. day ${ }^{-1}$ since. Therefore, $25 \%$ of the snow and ice ablation increase observed since 1982 is due to snow ablation intensification and not to an increase in snow ablation duration. As a consequence, because of earlier and higher snow melt, the date when the balance equals zero has therefore come forward by an average of 13 days from 31 to 17 August. Of course, this analysis being limited for years with negative budget, ice ablation tends to occur therefore earlier after 1982, as analysed hereafter in Sect. 4.2. In accordance with our observations at Sarennes, shorter snow cover duration is particularly well documented at lower altitudes in the French Alps over 1958-2007 (Durand et al., 2009b). Note that the present results for snow ablation rate changes differ slightly from those calculated for Sarennes by Vincent et al. (2004). This is due to a shorter period of record (1954-2002) in that previous paper. Moreover, for comparison with Claridenfirn, the 1 June was taken as a conventional fixed date for the beginning of the ablation season for the two glaciers.

\subsubsection{Snow degree-day factor}

With respect to temperature, a lot of studies have reported strong correlations with snow or ice ablation (e.g. Sicart et al., 2008). Considering summer centred balances at Sarennes measured throughout the ablation season, mean temperatures recorded at Lyon correlate well ( $r=-0.76$; Table 2). This correlation rises to -0.94 when considering trends over the 6 decades of record (Table 3). Such high correlations establish the empirical basis of well known positive degree-day (PDD) models relating melt to positive temperature sums (Hock, 1999, 2003). Considering measurements performed at stake 4 alone, Fig. 10 shows ablation during the snow ablation periods as a function of the cumulated positive temperatures calculated for the glacier from Lyon data with the vertical lapse rate of $6.25^{\circ} \mathrm{C} \mathrm{km}^{-1}$ identified in Sect. 2 under summer conditions. Using the numerous ablation measurements (a total of 253) performed each year during the ablation season, we identify a degreeday factor of $0.41 \mathrm{~cm}$ w.e. ${ }^{\circ} \mathrm{C}^{-1} \mathrm{day}^{-1}$ for snow ablation, with a strong correlation of $r=0.89$. Our result is close to the values of $0.38 \mathrm{~cm}$ w.e. ${ }^{\circ} \mathrm{C}^{-1}$ day $^{-1}$ reported by Vallon and Vincent (1997) for Sarennes over a shorter time frame, and $0.4 \mathrm{~cm}$ w.e. ${ }^{\circ} \mathrm{C}^{-1} \mathrm{day}^{-1}$ for the Saint-Sorlin glacier located $3 \mathrm{~km}$ from Sarennes (Vincent, 2002). Our value of $0.41 \mathrm{~cm}$ w.e. ${ }^{\circ} \mathrm{C}^{-1}$ day $^{-1}$ is in very good agreement with data reported in the compilation of Hock (2003), where sensitivities for snow range from 0.27 to $1.16 \mathrm{~cm}$ w.e. ${ }^{\circ} \mathrm{C}^{-1}$ day $^{-1}$ with a mean of $0.48 \mathrm{~cm}$ w.e. ${ }^{\circ} \mathrm{C}^{-1} \mathrm{day}^{-1}$. Braithwaite and Zhang (2000) provide very close values with a mean of $0.41 \mathrm{~cm}$ w.e. ${ }^{\circ} \mathrm{C}^{-1} \mathrm{day}^{-1}$ in the range 0.28 and $0.57 \mathrm{~cm}$ w.e. ${ }^{\circ} \mathrm{C}^{-1}$ day $^{-1}$.

Our result is unchanged if the analysis is performed separately on the two periods identified by the analysis of variance, indicating stable sensitivity to temperature for snow melting over the 6 decades of record. Figure 11 shows that this snow degree-day factor, despite being somewhat variable $\left(0.41 \pm 0.08 \mathrm{~cm}\right.$ w.e. $\left.{ }^{\circ} \mathrm{C}^{-1} \mathrm{day}^{-1}\right)$, is rather stable along the 6 decades of record at Sarennes. Therefore, we do not identify at Sarennes a decreasing trend in snow ablation sensitivity, as reported by Huss et al. (2009) since the 60s and 


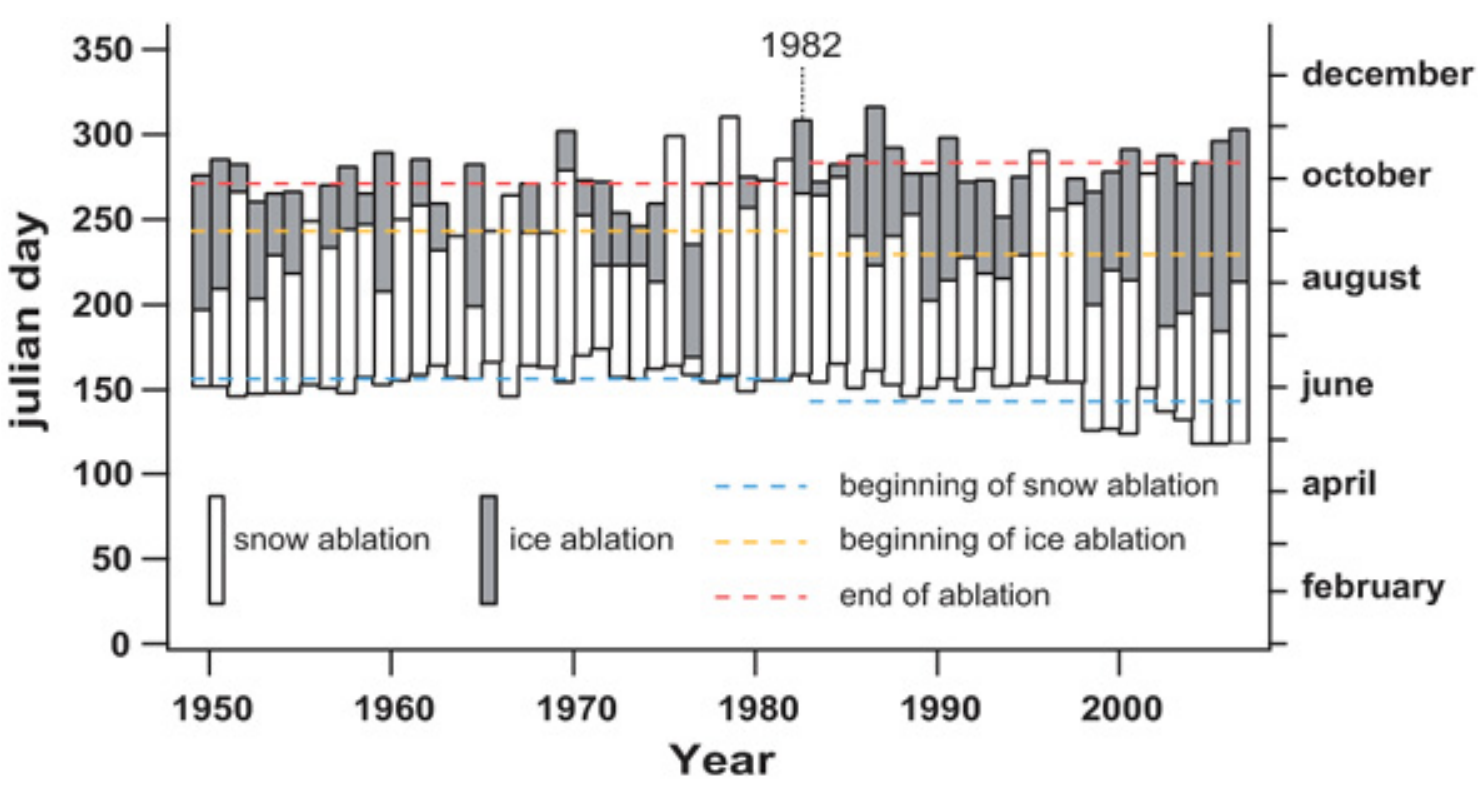

Fig. 9. Ablation start, end and duration for snow and ice at stake 4 over the 6 decades at Sarennes. Dashed lines are mean values before and after the breakpoint identified in 1982 for the summer balance.

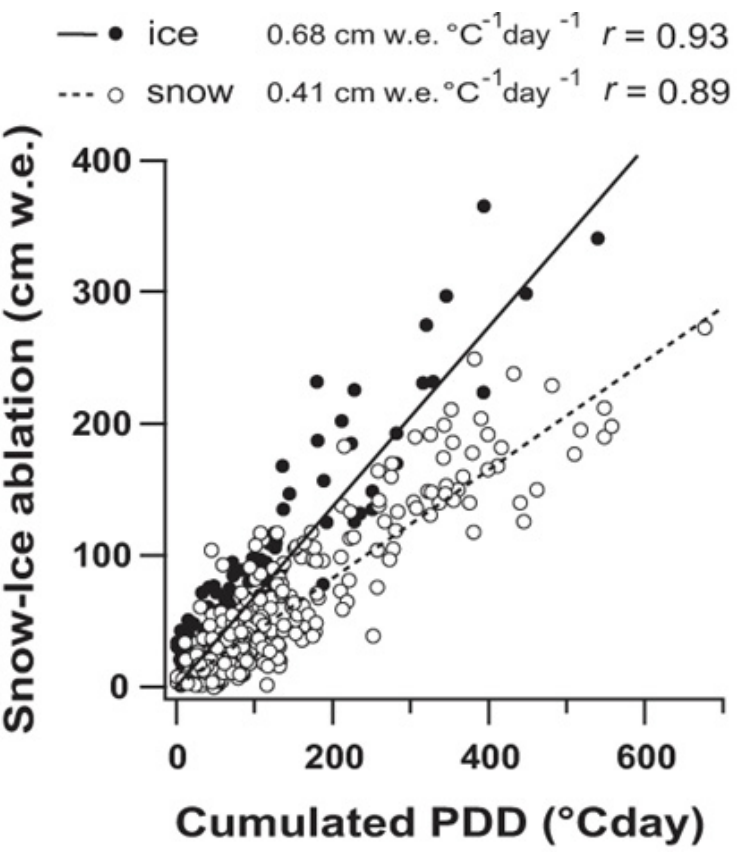

Fig. 10. Measured ablation at stake 4 for snow and ice as a function of the cumulated positive degree day calculated from Lyon with a vertical lapse rate of $6.25^{\circ} \mathrm{C} \mathrm{km}^{-1}$.

resulting from a detailed analysis of long ablation time series on 3 glaciers in the Swiss Alps.

As plotted in Fig. 4a, the Lyon temperature series shows a smooth, relatively continuous change centred in the mid 1970 s with a mean temperature shift of nearly $+1{ }^{\circ} \mathrm{C}$ since

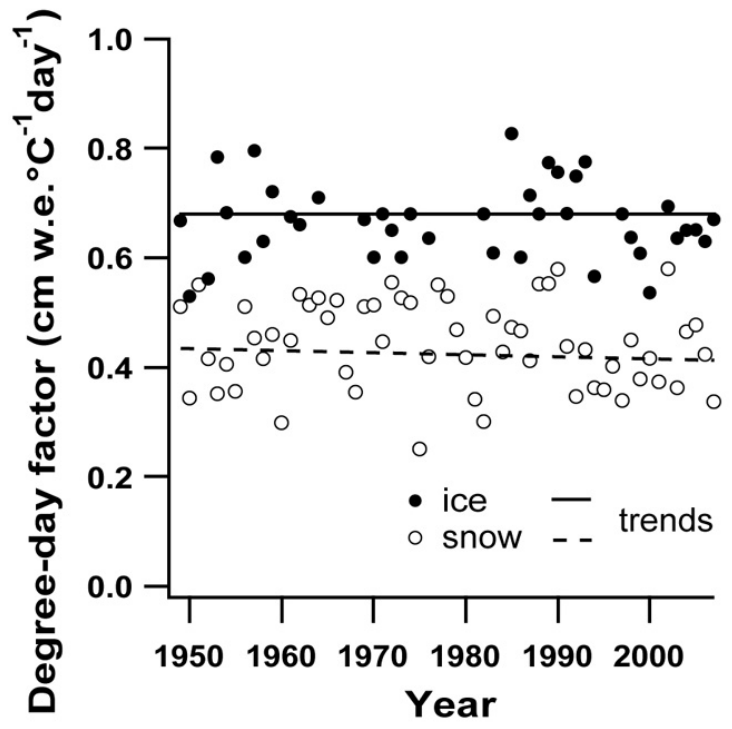

Fig. 11. Degree-day factors for snow and ice along the 6 decades at Sarennes at stake 4 . Lines refer to trends which are not significant. Ice ablation has occurred on $41 \mathrm{yr}$ among the $59 \mathrm{yr}$ of the record.

1974 for May to October. Because of the difficulty of segmenting the series into two clear sub-periods, we have adopted for the following analysis the two sub-periods identified for the summer balance, with the breakpoint occurring in 1982. Consequently, two curves have been plotted in Fig. 12 reporting raw and Gaussian smoothed mean daily temperatures above $0{ }^{\circ} \mathrm{C}$ at Sarennes (PDD) calculated from the Lyon data for the two periods 1949-1982 and 1983-2007. 
Figure 12 illustrates two main effects of warming during the ablation season:

1. Earlier snow ablation after 1982 with the number of days with mean positive temperatures increasing from 119 to 142 after 1982: these 23 additional days are very close to the 24 additional ablation days measured at stake 4 , and show a similar distribution with 15 additional days above zero in May associated with ablation starting 13 days earlier.

2. Higher snow ablation rates due to higher temperatures: Using the snow degree-day factor of $0.41 \mathrm{~cm}$ w.e. ${ }^{\circ} \mathrm{C}^{-1}$ day $^{-1}$ identified above, an additional snow ablation of $0.23 \mathrm{~m}$ w.e. is predicted since 1982 using the two temperature curves of Fig. 12, taking into account the change in the winter balance. This is in very good agreement with $0.28 \mathrm{~m}$ w.e. additional snow ablation measured at stake 4 (Table 5). Higher winter balances since 1976 have therefore been balanced by higher snow melt rates in relation to higher temperatures, resulting in almost constant snow ablation durations.

\subsubsection{Sensitivity of equilibrium-line altitude to temperature}

The preceding analysis can be used to quantify the sensitivity of equilibrium-line altitude (ELA) to temperature. Over the 6 decades of record, the mean winter accumulation on the glacier is $\left\langle B^{\mathrm{w}}\right\rangle=1.69 \mathrm{~m} \mathrm{w}$.e. $\mathrm{yr}^{-1}$, with a very low spatial (altitudinal) dependence (Eckert et al., 2011). Using the snow degree-day factor of $0.41 \mathrm{~cm}$ w.e. ${ }^{\circ} \mathrm{C}^{-1} \mathrm{day}^{-1}$, this requires a degree-day amount of $412{ }^{\circ} \mathrm{C} \mathrm{day}^{-1}$ cumulated over the whole ablation season. Using a vertical lapse rate of $6.25^{\circ} \mathrm{C} \mathrm{km}^{-1}$ and Lyon temperatures, the mean altitude satisfying such a PDD sum is $3100 \mathrm{~m}$. This altitude represents the mean ELA over 6 decades for this $45^{\circ} \mathrm{N}$ latitude southaspect Alpine glacier. Enhancing the mean temperature of $1{ }^{\circ} \mathrm{C}$ would increase the PDD sum by $138^{\circ} \mathrm{C}_{\text {day }}{ }^{-1}$ over the ablation season, yielding to a $0.57 \mathrm{mw}$.e. additional snow melt. Using a mass balance gradient with altitude in the range $0.7-0.8 \mathrm{~m}$ w.e. $\mathrm{yr}^{-1}(100 \mathrm{~m})^{-1}$ (Haeberli and Hoelzle, 1993), this will give an ELA sensitivity to temperature of $70-80 \mathrm{~m}^{\circ} \mathrm{C}^{-1}$. This is in agreement with Oerlemans (2001) for Alpine glaciers and a little higher than the value predicted by Vincent (2002) inferred from an analogous empirical PDD analysis on four glaciers in the French Alps. However, Fig. 12 shows that an increase in temperature of $1{ }^{\circ} \mathrm{C}$ also increases the number of days with a positive temperature because the positive temperature curve widens. Since the PDD sum corresponds to the area under this curve (counted in degree-day unit), the lengthening of the ablation season has to be accounted for. Vincent's (2002) analysis did not account for it, which probably underestimates the sensitivity by $10 \%$. Moreover, note that both of these PDD results are strongly dependent on the adopted vertical lapse rate (Caidong and Sorteberg, 2010).

Our ELA sensitivity is well below the range of $120-160 \mathrm{~m}^{\circ} \mathrm{C}^{-1}$ reported by Oerlemans and Hoogendoorn (1989), Vallinga and Van de Wal (1998), Greene et al. (1999), Maish (2000), Gerbaux et al. (2005), Gerbaux et al. (2005) and Zemp et al. (2007). On the one hand, higher sensitivity can be explained by smaller mass balance gradient like that of $0.58 \mathrm{~m}$ w.e. $\mathrm{yr}^{-1}(100 \mathrm{~m})^{-1}$ as reported by Gerbaux et al. (2005) near the equilibrium line, which would result in a sensitivity of $98 \mathrm{~m}^{\circ} \mathrm{C}^{-1}$. Measurements from the 5 stakes at Sarennes also suggest a lower gradient of $0.61 \mathrm{~m}$ w.e. $\mathrm{yr}^{-1}(100 \mathrm{~m})^{-1}$ between 2800 and $3000 \mathrm{~m}$ a.s.l. that would result in $93 \mathrm{~m}^{\circ} \mathrm{C}^{-1}$. On the other hand, a lower ELA sensitivity could be related to the empirical PDD estimate of snow ablation sensitivity to temperature and the effect of negative feedback loops.

Quantifying ELA sensitivity to temperature from empirical regression of ablation to degree days integrates the effect on ablation not only of the measured temperature variations but also of all other meteorological parameters that control ablation and which may have changed along with temperature over the period of record (summer and winter precipitation, downward long-wave radiation, cloud cover, moisture and global radiation). These parameters can induce both positive and negative feedbacks to raise or lower the altitude of the equilibrium line. In contrast, quantifying ELA sensitivity from physical models provides information about sensitivity to various meteorological parameters both separately and, as needed, in combination. Winter balance change is an example of negative feedback as atmospheric temperature rises. If we expect milder and moister winters, we would expect larger winter balances that would delay melting in summer and thus lower the ELA. As seen in the previous section, this feedback has been exactly balanced at Sarennes by the snow melt rate rise in relation to higher air temperatures. The same applies if more precipitation occurs as snow at high altitude: This would reduce summer ablation through the albedo feedback. A typical positive feedback is long-wave radiation emitted from the low troposphere that would increase along with warmer temperatures. Sensitivity of the ELA is found to increase by $28 \%$ (Gerbaux et al., 2005) for the long-wave irradiance rise associated with $+1{ }^{\circ} \mathrm{C}$ of warming - a strong feedback.

Being based on PDD regression, our ELA sensitivity is quantified with a mean snow degree-day factor that integrates all sources of variation that may be associated with temperature changes over 6 decades. PDD-based quantification of ELA change therefore necessarily remains an unrefined estimate compared to estimates based on physical models. Furthermore, another limitation quantifying ELA sensitivity from a snow degree-day factor is that the vertical gradient of mass balance should not be a constant if climate is changing (Oerlemans and Hoogendoorn, 1989; Gerbaux et al., 2005). It is therefore difficult to draw any firm conclusion from the 
comparison of different ELA sensitivity derived from different approaches, ranging from empirical (mass balance and climate observations) to surface energy balance modelling. Care should be taken when relating future changes in glacier equilibrium-line altitudes to temperature changes using ELA sensitivity estimates which differ so much in their physical content.

Nevertheless, a complementary result which can be drawn from this analysis is that a precipitation change of $+34 \%$ should compensate a temperature increase of $+1{ }^{\circ} \mathrm{C}$, assuming a linear response. This corresponds to an absolute change of $+0.57 \mathrm{~m}$ w.e. $\mathrm{yr}^{-1}$, which is in agreement with the result of $+0.5 \mathrm{~m}$ w.e. $( \pm 28 \%)$ reported by Gerbaux et al. (2005) on Saint-Sorlin glacier (5 km from Sarennes) using a physically based energy mass balance model. Our result is also in agreement with the $+25-30 \%$ range for precipitation change given by Vincent (2002) based on field observations on four others glaciers in the northern French Alps.

\subsection{Ice ablation}

\subsubsection{Intensity and duration}

Considering all years of the record (including years with and without ice ablation), ice ablation has on average increased by $0.83 \mathrm{~m}$ w.e. $\mathrm{yr}^{-1}$ after 1982 . Therefore $75 \%$ of the ablation increase since $1982\left(+1.1 \mathrm{mw}^{-e} . \mathrm{yr}^{-1}\right)$ is explained by ice ablation alone. However, among the $59 \mathrm{yr}$ of recorded mass balances, only 17 are positive mass balance years with solely snow ablation, and $13(76 \%)$ of these occurred before 1982 . Considering exclusively the negativebalance years over six decades of record, and again considering the 1949-1982 and 1983-2007 periods, ice ablation measured at stake 4 has increased by $0.73 \mathrm{~m}$ w.e. $\mathrm{yr}^{-1}$ from $1.07 \mathrm{~m}$ w.e. $\mathrm{yr}^{-1}$ to $1.80 \mathrm{~m}$ w.e. $\mathrm{yr}^{-1}$ (Table 5). Both ice ablation duration and ice ablation rates explain this shift. The ablation season has lengthened by 24 days, and longer-lasting ice ablation explains all the increase in the ablation period since 1982, with the snow ablation period essentially remaining constant. Ice ablation lasted 29 days before 1982 and 53 days since, beginning 13 days earlier and ending 11 later (Fig. 9). Above and beyond its duration, ice ablation has also intensified: Ablation rates increased by $0.25 \mathrm{~cm}$ w.e. day $^{-1}$ (nearly $10 \%$ ) since 1982 between $2.50 \mathrm{~cm}$ w.e. day ${ }^{-1}$ and $2.75 \mathrm{~cm}$ w.e. day ${ }^{-1}$. The main part $(87 \%)$ of the rise in ice ablation is thus due to the extension of the ablation period, and only $13 \%$ is due to melt intensification.

\subsubsection{Ice degree-day factor}

Analyzing ice ablation as function of positive degree day calculated from Lyon data, Fig. 10 reports 144 measurements performed along the ice ablation period over the 6 decades of record, indicating a degree-day factor of $0.68 \mathrm{~cm}$ w.e. ${ }^{\circ} \mathrm{C}^{-1} \mathrm{day}^{-1}$ for ice ablation with a good cor- relation $(r=0.93)$. The ice ablation record at stake no. 2 downhill was also analyzed, and a little bit higher degreeday factor is found with $0.71 \mathrm{~cm}$ w.e. ${ }^{\circ} \mathrm{C}^{-1}$ day $^{-1}$, while Vincent and Vallon found $0.62 \mathrm{~cm}$ w.e. ${ }^{\circ} \mathrm{C}^{-1}$ day $^{-1}$ at stake no. 3 over a shorter analyzed period (1949-1994). These results are consistent considering the variability in the time series as well as the spatial variability that is expected from albedo and roughness at the glacier surface. They are also in the range given by Laumann and Reeh (1993) for glaciers in Norway, and by Hock (1999) in Sweden. Again, in the compilation of Hock (2003), a mean of $0.87 \mathrm{~cm}$ w.e. ${ }^{\circ} \mathrm{C}^{-1}$ day $^{-1}$ is reported for 33 values ranging from 0.55 to $2 \mathrm{~cm}$ w.e. ${ }^{\circ} \mathrm{C}^{-1} \mathrm{day}^{-1}$. Considering only Alpine glaciers, Braithwaite and Zhang (2000) report degree-day factors in the range $0.50-0.94 \mathrm{~cm}$ w.e. ${ }^{\circ} \mathrm{C}^{-1}$ day $^{-1}$, which is consistent with our value of $0.68 \mathrm{~cm}$ w.e. ${ }^{\circ} \mathrm{C}^{-1}$ day $^{-1}$.

As reported for snow, within the variability of $\pm 0.07 \mathrm{~cm}$ w.e. ${ }^{\circ} \mathrm{C}^{-1}$ day $^{-1}$, we do not see any specific trend or time structure in the ice degree-day factor over the 6 decades at Sarennes (Fig. 11). It is somewhat difficult to draw a firm conclusion when comparing such factors or detecting possible trends for long-term records because such coefficients remain empirical. Based on correlation, these degree-day factors integrate other sources of fluctuation that may have contributed to melt along with temperature variations over 6 decades of ablation seasons. Regarding ice ablation, an important retroaction is a possible decrease in ice albedo as reported in recent years on many Alpine glaciers (e.g. Oerlemans et al., 2009). We do not have the kind of long-term records of energy balance that are presented in that paper to support any firm conclusion as to whether albedo has changed or not over the latter years of the record. It is however interesting to quantify how the ice degree-day factor may be affected by a change in albedo. Some one-off measurements of ice albedo have been made in October 2011 indicating $\alpha=0.43 \pm 0.04$ at 5 locations on the glacier in the ablation area. This value is typical for clean ice (Paterson, 1994), and Sarennes is indeed relatively free of debris and dust. Ice albedo at Sarennes was therefore high in 2011, and it is rather difficult to consider that it was considerably higher in the past as a maximum of 0.51 is known for very clean ice.

Nevertheless, assuming a decrease in albedo from 0.51 at the beginning of the record to 0.43 as measured in 2011, it is possible to calculate the impact on surface energy balance. Over a typical 39-day ice ablation period (22 August30 September, Table 5) at the latitude of Sarennes $\left(45^{\circ} 07^{\prime} \mathrm{N}\right)$, the mean global radiation at the top of the atmosphere is $310 \mathrm{Wm}^{-2}$, taking into account shading and glacier slope. Using a total effective atmospheric transmittance of 0.64 inferred from our weather station data (unpublished results), we consider a mean global radiation of $200 \mathrm{Wm}^{-2}$ during the ice ablation period. If the mean albedo over 1949-2007 is 0.47 (decreasing from 0.51 to 0.43 ), the mean short wave net flux is $106 \mathrm{Wm}^{-2}$ (increasing from 98 to $114 \mathrm{Wm}^{-2}$, i.e. 


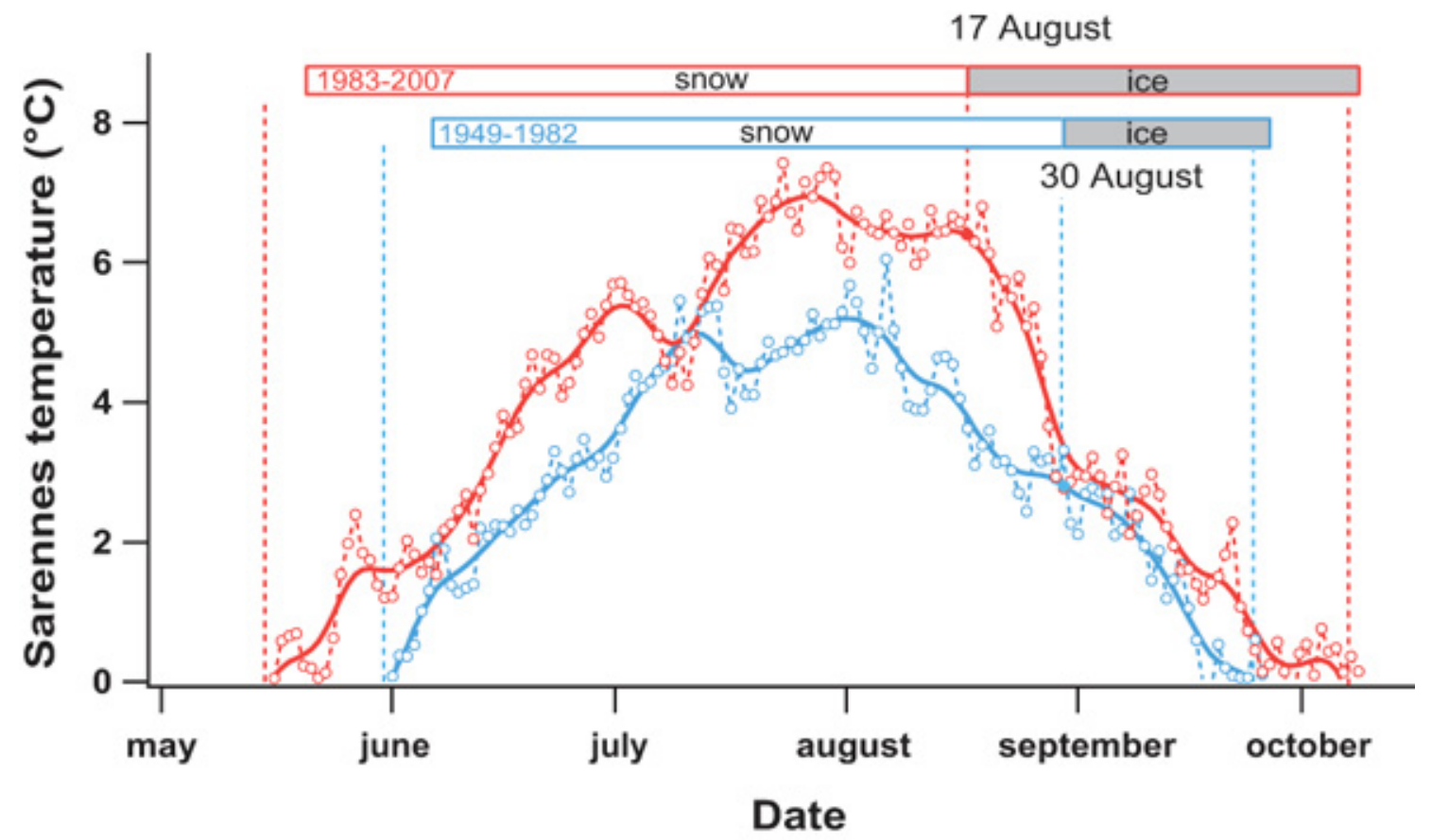

Fig. 12. Mean daily temperature above $0^{\circ} \mathrm{C}$ at Sarennes (3000 m) between 1949-1982 (blue curve) and 1983-2007 (red curve), explaining the lengthening of the ablation season with earlier snow melt in May, earlier ice melt in August and later ice melt in October according to the PDD model. Dashed lines and markers are raw daily means while continuous lines are Gaussian smoothed daily means. Horizontal bars are measured average ablation durations at stake 4 for snow (white) and ice (grey) for the two periods.

$+16 \mathrm{Wm}^{-2}$ between 1949 and 2007). All other components of the surface energy balance being kept the same, this additional energy flux would cause ablation forcing of $0.16 \mathrm{~m}$ w.e. over the 39 days of the ice ablation season, using a latent heat of melting for ice of $335 \mathrm{~kJ} \mathrm{~kg}^{-1}$. This melting change is divided in $-0.08 \mathrm{~m}$ w.e. and $+0.08 \mathrm{~m}$ w.e. around the middle of the period of record, roughly 1980 . As mean ice ablation has changed by $+0.73 \mathrm{~m}$ w.e. between the two periods identified in our study (Table 5), this change in albedo could contribute to $11 \%$ of the melt change around the mean value.

Considering that mean ice ablation measured over the overall period of record (1949-2007) is $1.01 \mathrm{~cm}$ w.e. $\mathrm{yr}^{-1}$ for a $148^{\circ} \mathrm{C}^{-1 a y}{ }^{-1}$ sum (degree-day factor $0.68 \mathrm{~cm}$ w.e. ${ }^{\circ} \mathrm{C}^{-1} \mathrm{day}^{-1}$ ), if the albedo change is not taken into account, the ablation change distorts the sensitivity by $\pm 8 \mathrm{~cm}$ w.e. over a PDD sum of $148^{\circ} \mathrm{C}_{\text {day }}{ }^{-1}$, i.e. $\pm 0.054 \mathrm{~cm}$ w.e. ${ }^{\circ} \mathrm{C}^{-1} \mathrm{day}^{-1}$. In consequence, the correct degree-day factor should be in the range of 0.63 $0.73 \mathrm{~cm}$ w.e. ${ }^{\circ} \mathrm{C}^{-1} \mathrm{day}^{-1}$. The effect of albedo change on the ice degree-day factor is therefore limited, of the same order of magnitude as its year-to-year variability (Fig. 11). This is due to the high albedo that we know for this glacier $(0.43$ in 2011) and the relatively short duration of the ice ablation period (39 days in mean) in relation to the high altitude of the glacier (2840-3050 m a.s.1.). Similarly, this unsuspected albedo change would be (wrongly) interpreted in an equivalent atmospheric temperature change of $\pm 0.12{ }^{\circ} \mathrm{C}$ using a
PDD model, and assuming a constant degree-day factor. In any case, this corresponds to only $9 \%$ of the temperature change measured by the Lyon weather station since 1982.

Summing up, ice albedo may have changed at Sarennes since the beginning of the record, but this cannot be retrieved from our data, particularly from the time evolution of ice degree-day factor. Any albedo change would have a limited impact on our results: We estimate that a maximum of $11 \%$ of the ice ablation rise recorded after 1982 could be due to a decrease in ice albedo. This would be responsible for a forcing of $+16 \mathrm{Wm}^{-2}$ in the surface energy balance during the ice ablation period which could be misinterpreted in an equivalent temperature rise of $+0.12^{\circ} \mathrm{C}$.

Considering the limitations exposed above, the effect of temperature rise on ice ablation rates and duration can be satisfactorily explained by the degree-day analysis of Fig. 12:

1. The autumn 11-day lengthening of the ice ablation season observed after 1982 from direct measurements is well explained by the number of additional days with mean positive temperatures in September-October at Sarennes (10 days as calculated on the basis of Lyon data). The 13-day earlier ice melt in August results also in higher melt rates, independently of the temperature rise, because average mid-August daily temperatures exceed those of September by $1.6^{\circ} \mathrm{C}$. 
2. Higher ice ablation due to higher and longer-lasting positive temperature is also quantitatively explained. Using the ice degree-day factor of $0.68 \mathrm{~cm}$ w.e. ${ }^{\circ} \mathrm{C}^{-1} \mathrm{day}^{-1}$ identified above, an additional ice ablation of $0.79 \mathrm{~m}$ w.e. is predicted after 1982 using the two temperature curves of Fig. 12. This is in good agreement with $0.73 \mathrm{~m}$ w.e. additional ice ablation measured at stake 4 after 1982 (Table 5).

\subsubsection{Sensitivity of summer balance to temperature}

The sensitivity of ablation to temperature variations over the whole summer period can be deduced from our snow and ice ablation analysis over the last 6 decades. For this, the degree-day factor has been multiplied by the number of days when temperatures are positive. With a mean ablation period of 125 days, including 86 days of snow ablation and 39 days of ice ablation, we use a mean snow-ice degree-day fac-

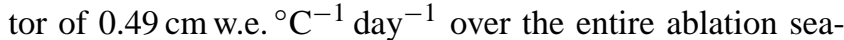
son. This yields an ablation sensitivity of $-0.62 \mathrm{~m}$ w.e. ${ }^{\circ} \mathrm{C}^{-1}$ at $3000 \mathrm{~m}$. A similar analysis at stake $2,83 \mathrm{~m}$ lower in altitude (Fig. 1), gives $-0.64 \mathrm{mw}$.e. ${ }^{\circ} \mathrm{C}^{-1}$ at $2917 \mathrm{~m}$, taking into account the fact that ice ablation lasts 10 days longer at this stake on average. This result is reasonable as the sensitivity of summer balance is known to increase (in absolute value) at lower elevations (Vallon et al., 1998; Braithwaite and Zhang, 2000; Vincent, 2002). From these two estimations, the altitude dependence of summer balance sensitivity to temperature is $1.2 \mathrm{~m}$ w.e. ${ }^{\circ} \mathrm{C}^{-1}(1000 \mathrm{~m})^{-1}$. Because the altitude range at Sarennes is small $(150 \mathrm{~m})$, it is difficult to judge whether or not this value is a reliable estimate of the altitudinal dependence of sensitivity, even taking into account data from other stakes. However, this result is within the range of 0.8 to $1.3 \mathrm{~m}$ w.e. ${ }^{\circ} \mathrm{C}^{-1}(1000 \mathrm{~m})^{-1}$ from Vallon et al. (1998) and Braithwaite and Zhang (2000), respectively.

Depending on the relative snow and ice ablation durations, this sensitivity cannot be considered as a constant over 6 decades. As ice is exposed for a longer time over the ablation season since 1982, the mass balance sensitivity is expected to have increased (in absolute value) since the degree-day factor for ice exceeds the snow factor by a ratio of 1.7. Considering the changes in ice ablation duration (Table 5), the sensitivity of the mass balance can be calculated as above with mean (entire season) snow-ice degree-day factors of 0.48 and $0.51 \mathrm{~cm}$ w.e. ${ }^{\circ} \mathrm{C}^{-1}$ day $^{-1}$ before and after 1982 , respectively. This results in a sensitivity to temperature varying between -0.55 and $-0.71 \mathrm{mw}$.e. ${ }^{\circ} \mathrm{C}^{-1}$ at $3000 \mathrm{~m}(+26 \%)$. This is clearly an albedo feedback at this altitude close to the equilibrium line. As climate warms, the sensitivity of the mass balance is therefore expected to increase. Above the equilibrium line, this depends on how the ablation season lengthens. Under, this depends also on how the ice ablation duration expands relative to snow ablation duration. Most of the sensitivity increase is expected to occur in the area where the equilibrium line rises in altitude, i.e. where ice gets exposed to atmosphere in place of snow. This effect has also been reported by spatially distributed physically based surface mass balance models indicating a strong increase in mass balance sensitivity for glacier surfaces just below the ELA (e.g. Gerbaux et al., 2005).

As mentioned in Sect. 2.1, caution is warranted when it comes to long-term ablation changes in which a part might be due to the decrease in altitude of the glacier surface. Due to the vertical gradient of the mass balance, enhanced ablation at each measurement site can occur from year to year producing a long-term trend contribution to the mass balance. Altitude changes at Sarennes calculated from photogrammetric survey in 1952 and 2003 give a mean of $-36 \mathrm{~m}$ over $51 \mathrm{yr}$ (Thibert et al., 2008). This altitude loss occurred mainly before 1976 (one-third) and after 1982 (two-thirds) (Eckert et al., 2011), which results in mean annual rates of altitude loss of -0.51 and $-0.92 \mathrm{~m} \mathrm{yr}^{-1}$ over these two periods, respectively. Regarding the last period where most altitude change occurred, the forcing due to altitude loss can be calculated from the vertical gradient of the mass balance at Sarennes $\left(+0.61 \mathrm{~m}\right.$ w.e. $\left.\mathrm{yr}^{-1}(100 \mathrm{~m})^{-1}\right)$. This results in a contribution of $-0.56 \mathrm{~cm} \mathrm{w.e.} \mathrm{yr}^{-2}$ to the long-term trend in annual balance. As the long-term trend in annual balance over the $1983-2007$ period is $-3.54 \mathrm{cmw}$ e. $\mathrm{yr}^{-2}$ (from Fig. 2a of this paper), a maximum of $16 \%$ of the long-term trend in annual balance can be explained by forcing due to altitude loss. In terms of temperature forcing, an equivalence of the $-0.56 \mathrm{~cm}$ w.e. $\mathrm{yr}^{-2}$ can be quantified using the sensitivity of mass balance to temperature identified above $\left(-0.62 \mathrm{~m}\right.$ w.e. $\left.\mathrm{yr}^{-1}{ }^{\circ} \mathrm{C}^{-1}\right)$. This gives an equivalence of $+9.10^{-3}{ }^{\circ} \mathrm{C} \mathrm{yr}^{-1}$ over the last $25 \mathrm{yr}$ of recording $\left(+0.22{ }^{\circ} \mathrm{C}\right.$ over $\left.25 \mathrm{yr}\right)$. From the temperature records (Fig. 4a), this is nearly $13 \%$ of the long-term trend which is about $+0.0712^{\circ} \mathrm{C} \mathrm{yr}^{-1}\left(+1.78^{\circ} \mathrm{C}\right.$ over $\left.25 \mathrm{yr}\right)$. From these two calculations, we can conclude that, without being negligible, the altitude loss at Sarennes has a limited effect on the mass balance record, and its long-term trend is only slightly affected by surface elevation change.

Summing up, $75 \%$ of ablation variations since the last $25 \mathrm{yr}$ of the record are explained by the increased ice ablation in the summer balance component of the mass balance. This is mainly driven by the 24-day lengthening of the ablation period in late summer-early autumn and, to a lesser extent, by higher snow and ice ablation rates over the whole ablation period. The lengthening of the ablation period accounts therefore for $65 \%$ of the ablation increase observed during the summer season. $35 \%$ is related to higher ablation rates, in which snow and ice account for $25 \%$ and $10 \%$, respectively. Temperature - which exhibits common variance - can be used as an explanatory variable: Between the two periods separated by the 1982 breakpoint, monthly temperatures between May and October have indeed increased by $+1.32^{\circ} \mathrm{C}$, and those in September to October by $+1.2^{\circ} \mathrm{C}$.

In the relative importance of prolongation of the melting season $(65 \%)$ and higher air temperatures $(35 \%)$ on 
the mass balance change, the direct effect of temperature may appear small at Sarennes. This is due to the high altitude of this glacier (between 2900-3000 m a.s.1.) with surfaces close to the equilibrium line. As reported in many papers, sensitivity of the mass balance decreases with altitude (Vallon et al., 1998; Braithwaite and Zhang, 2000; Gerbaux et al., 2005). From our data, the sensitivity is around $-0.6 \mathrm{~m}$ w.e. $\mathrm{yr}^{-1}{ }^{\circ} \mathrm{C}^{-1}$ at this altitude, while a sensitivity higher than $1 \mathrm{mw}$.e. $\mathrm{yr}^{-1}{ }^{\circ} \mathrm{C}^{-1}$ is expected around 2400 m a.s.1. (Vincent, 2002). Ablation at Sarennes altitude does not just depend on temperature, but also on albedo. Close to the equilibrium line, surface albedo depends on the winter balance and on the relative ablation duration for snow and ice throughout the season. At Sarennes, snow at the surface dominates for 86 days while ice is only exposed for 39 days. Long-lasting conditions for melting at the end of the ablation season do depend on temperature but also on when the first snow falls to end the ablation season. This confirms that, for studying climate from ablation in a more direct and sensitive way, lower-elevation glacier areas - where mass balance is a more direct and sensitive indicator - are more suited. However, our study shows that changes in the duration of ablation are also important as these, together with the rate of ablation, control the total amount of ablation over the melting season. This requires adopting the stratigraphic method for mass balance measurement rather than the fixeddate method (Cogley et al., 2011).

\subsection{Link with NAO anomalies}

Summer balance at Sarennes is significantly anti-correlated with NAO anomalies $(r=-0.33)$, and similar significant positive correlations are observed with Lyon temperature $(r=0.41)$, as expected from the high anti-correlation between summer balance and temperatures (Table 2). Again, these correlations are even stronger for trends than for the variables themselves (Table 3). More interestingly, it appears that correlations are much better with winter NAO series than with annual NAO anomalies and that the relevant signal is, as for winter balance, concentrated in the DJF series. Accordingly, Hurrell (1995) argues that NAO anomalies are not well defined over summer months due to a flatter pressure field. Indeed, correlations with the annual NAO signal, even smoothed, are not significant, and considering cumulative anomalies from November to April (which better represents the duration of accumulation conditions at high altitude) leads to correlations weaker than the DJF anomaly (Tables 2 and 3).

Since winter balance and DJF NAO anomalies are very weakly correlated, this negative correlation between summer balance and DJF NAO anomalies leads to a slightly negative correlation between winter NAO anomalies and Sarennes annual mass balance (Table 2), as has already been pointed out by (Six et al., 2001). This negative correlation is only statistically significant for smoothed signals (Fig. 7b,c and Ta- ble 3). This is compatible with the weak anti-correlation between NAO forcing and the mass balances of western European Alpine glaciers inferred at a much larger spatial scale by (Marzeion and Nesje, 2012). It also suggests that the dependence of the interannual variability of the Sarennes mass balance on the synoptic signal summarised in the NAO is much weaker than reported by Huss et al. (2010) between reconstructed mass balances of 100 Swiss glaciers and sea surface temperatures (SST) in the North Atlantic Ocean (Atlantic Multidecadal Oscillation). As stated in Sect. 2.4.1, this is reasonable since temperature signals are well correlated over large areas (Böhm et al., 2001) and temperature correlates highly with summer and annual balances. On the contrary, pressure fields correlate better with precipitation, whose spatial structure is much weaker.

Our finding however differs from previous results (Fealy and Sweeney, 2005; Marzeion and Nesje, 2012) which report a connection between winter balance and NAO stronger than that with annual balance. Indeed, as stated before, at Sarennes, annual balance is mainly conditioned by the summer balance, which accounts for $79 \%$ of the annual variance. The winter balance just controls $28 \%$ of the variability of the annual mass budget of the glacier, while winter and summer balances are uncorrelated. From our results concerning the relationship between NAO and the seasonal components of the balance, winter accumulation seems not to be ruled by the large-scale signal summed up in the NAO, as might be expected from other glaciers in the western Alps where NAO and winter balance are negatively correlated. The NAO seems to drive the annual balance exclusively through the summer balance. Hence, the only and tenuous connection to the annual balance $(r=-0.25$; non-significant) indeed consists in a higher link with summer balance $(r=-0.33$; significant). This is summarised in the significant but weak correlation $(r=0.41)$ between DFJ NAO and Lyon summer temperatures. We suspect that this weak influence on summer balance to be exerted by temperatures at the beginning of the ablation season in late spring. Since winter anomalies are associated with high pressure blocking events in the Alps, inducing downward vertical atmospheric circulation, decreasing cloudiness, and thus persistent warming, the occurrence of such events under persistent and long-lasting conditions as reported by Beniston and Jungo (2002) could be an explanation.

\section{Conclusions}

The winter and summer mass balances recorded at Glacier de Sarennes since 1949 have been related to large (NAO) and glacier-scale forcing drivers in terms of annual fluctuations, breaks in the time series and trends of the low-frequency signals.

Winter accumulation at the high altitude of Glacier de Sarennes is closely related to valley precipitation with 
about $65 \%$ of common variance. Nevertheless, the ratio between accumulation and precipitation recorded in valley weather stations is up to 2.5 for an altitude difference of $1500 \mathrm{~m}$, which represents an average altitudinal gradient of $840 \mathrm{~mm}(1000 \mathrm{~m})^{-1}$ of annual precipitation. This is 4 times the value expected from large-scale altitudinal orographic gradients which identify specific accumulation processes depending on basin topography. Regarding the temporal evolution of the winter balance, the sudden winter balance shift identified in 1976 is well documented in the western Alps. This is related to higher precipitations occurring in early and late winter months and could be associated with milder winters over the last $30 \mathrm{yr}$, especially in late winter.

With respect to summer balance time series, a break is detected in 1982, and two explanatory processes underlie the very large increase of $1.1 \mathrm{~m}^{\mathrm{w}}$.e. $\mathrm{yr}^{-1}$ in ablation: changes in both ablation duration and ablation rate. Lengthening explains around $65 \%$ of the ablation rise with the ablation period tending to start 13 days earlier in spring and to end 11 days later in autumn. Snow ablation duration is mostly constant over 6 decades, so prolongation of the ablation season is due to a 24-day lengthening of the ice ablation period. An increase in ablation rates also contributes to the summer balance change, with similar shifts for snow and ice $\left.\left(0.25-0.27 \mathrm{~cm} \mathrm{w.e.}^{-1}\right)^{-1}\right)$. These changes in ablation rate contribute to a lesser extent $(35 \%)$ to the summer balance increase observed over the last $25 \mathrm{yr}$ of the record. The lowering of the glacier surface has a limited impact on Sarennes summer balance changes. An upper limit of $16 \%$ of the longterm trend can be identified. Its equivalence in atmospheric temperature forcing is $+0.22^{\circ} \mathrm{C}$ while $+1.78^{\circ} \mathrm{C}$ is observed over the last $25 \mathrm{yr}$ of the record.

From a single temperature analysis based on a simple degree-day model, more than $80 \%$ of summer balance variations can be explained by the atmospheric temperature rise since the early 80 s, explaining quantitatively both ablation lengthening and intensification. From the direct measurements performed at Sarennes, snow and ice degree-day factors are stable over the 6 decades of record, and no specific trend or time structure is detected in snow ablation sensitivity to temperature as reported by Huss et al. (2009) in an analysis of a long time series for 3 glaciers in the Swiss Alps.

The mean ELA of this $45^{\circ} \mathrm{N}$ latitude south-facing glacier was $3100 \mathrm{~m}$ a.s.l. between 1949 and 2007. Around this mean position, the sensitivity of the equilibrium-line altitude to temperature change is about $93 \mathrm{~m}^{\circ} \mathrm{C}^{-1}$, although this is highly dependent on the adopted altitudinal dependence of mass balance, which is $+0.61 \mathrm{~m}$ w.e. $\mathrm{yr}^{-1}(100 \mathrm{~m})^{-1}$ at Sarennes. Regarding the sensitivity of the summer balance to temperature change, a value of $-0.62 \mathrm{mw}$.e. $\mathrm{yr}^{-1}{ }^{\circ} \mathrm{C}^{-1}$ can be derived assuming a 125-day ablation period at $3000 \mathrm{~m}$ a.s.l, as observed over the last 6 decades. However, the last $25 \mathrm{yr}$ of the record have seen increases of this sensitivity $(+26 \%)$ due to the expansion of the ice ablation duration and an albedo feedback close to the ELA.
The break in the times series and the linear trends indicated by the Sarennes observations correspond well to those observed in local climate covariates. They are not disconnected from large-scale patterns, e.g. they are consistent with the general context of warming since the middle of the 1970s. However, correlations between the different seasonal components of the balance and NAO anomalies have been found to be rather weak and therefore hard to interpret. Indeed, the NAO signal has to be smoothed over several years to obtain significant correlations which can generate artifacts. Furthermore, significant correlations only emerge for December to February NAO anomalies, and only for the summer balance. This finding is uncommon as the NAO is known to control winter precipitation in the Alps but to have a smaller influence on temperatures (Wanner et al., 2001). The winter balance as well as winter precipitation at the weather station in the vicinity seem disconnected from NAO deviations. Mass balance is connected to the NAO exclusively through the summer balance. Therefore, this study suggests that the climatic control of interannual variability on the Sarennes mass balance by the synoptic signal summarised in the NAO index is weak and linked to temperature rather than winter precipitation.

Acknowledgements. The authors are grateful to the numerous people that have permitted the constitution of Sarennes' exceptional data series, especially L. de Crécy and F. Valla. Thanks to their efforts, data collection has been, despite limited funds, nearly exhaustive during $60 \mathrm{yr}$. The last years of the record were funded by GLACIOCLIM Observatoire de Recherche en Environnement (ORE), Programme d'Observation des Glaciers (POG) and Observatoire des Sciences de l'Univers de Grenoble (OSUG, Institut des Sciences de l'Univers (INSU)). We thank also Météo-France for providing meteorological data. The authors are grateful to the scientific editor V. Radic and three anonymous reviewers whose comments and suggestions improved the clarity of the manuscript.

Edited by: V. Radic

\section{References}

Aellen, M. and Funk, M.: Bilan hydrologique du basin versant de la Massa et bilan de masse des glaciers d'Aletsch (Alpes Bernoises, Suisse), IHAS Publ., 193, 89-98, 1990.

Beniston, M.: Variations of snow depth and duration in the Swiss Alps over the last 50 years: links to changes in large-scale climatic forcing, Clim. Change, 36, 281-300, 1997.

Beniston, M.: Mountain Climates and Climatic Change: An Overview of Processes Focusing on the European Alps, Pure Appl. Geophys., 162, 1587-1606, 2005.

Beniston, M. and Jungo, P.: Shifts in the distributions of pressure, temperature and moisture and changes in the typical weather patterns in the Alpine region in response to the behavior of the North Atlantic Oscillation, Theor. Appl. Climatol., 71, 29-42, 2002. 
Beniston, M., Diaz, H. F., and Bradley, R. S.: Climatic change at high elevation sites: an overview, Clim. Change, 36, 233-251, 1997.

Böhm, R., Auer, I., Brunetti, M., Maugeri, M., Nanni, T., and Schöner, W.: Regional temperature variability in the European Alps 1760-1998 from homogenized instrumental time series, Int. J. Climatol., 21, 1779-1801, 2001.

Braithwaite, R. J.: On glacier energy balance, ablation and air temperature, J. Glaciol., 27, 381-391, 1981.

Braithwaite, R. J. and Zhang, Y.: Sensitivity of mass balance of five Swiss glaciers to temperature changes assessed by tuning a degree-day model, J. Glaciol., 46, 7-14, 2000.

Brooks, S. P.: Markov Chain Monte Carlo Method and its application, The Statistician, 47, 69-100, 1998.

Caidong, C. and Sorteberg, A. : Modelled mass balance of Xibu glacier, Tibetan Plateau: sensitivity to climate change, J. Glaciol., 56, 235-248, 2010.

Cogley, J. G., Hock, R., Rasmussen, L. A., Arendt, A. A., Bauder, A., Braithwaite, R. J., Jansson, P., Kaser, G., Möller, M., Nicholson, L., and Zemp, M.: Glossary of Glacier Mass Balance and Related Terms, IHP-VII Technical Documents in Hydrology No. 86, IACS Contribution No. 2, UNESCO-IHP, Paris, 2010.

Durand, Y., Laternser, M., Giraud, G., Etchevers, P., Lesaffre, B., and Mérindol, L.: Reanalysis of 44 year of climate in the French Alps (1958-2002): methodology, model validation, climatology, and trends for air temperature and precipitation, J. Appl. Meteorol. Climatol., 429-449, 2009a.

Durand, Y., Laternser, M., Giraud, G., Etchevers, P., Mérindol, L., and Lesaffre, B.: Reanalysis of 47 Years of Climate in the French Alps (1958-2005): Climatology and Trends for Snow Cover, J. Appl. Meteorol. Climatol., 48, 2487-2512, 2009b.

Eckert, N., Baya, H., and Deschâtres, M.: Assessing the response of snow avalanche runout altitudes to climate fluctuations using hierarchical modelling: application to 61 winters of data in France, J. Clim., 23, 3157-3180, 2010.

Eckert, N., Baya, H., Thibert, E., and Vincent, C.: Extracting the temporal signal from a winter and summer mass-balance series: application to a six-decade record at Glacier de Sarennes, French Alps. J. Glaciol., 57, 134-150, 2011.

Elsberg, D. H., Harrison, W. D., Echelmeyer, K. A., and Krimmel, R. M.: Quantifying the effect of climate and surface change on glacier mass balance, J. Glaciol., 47, 649-658, 2001.

Fealy, R. and Sweeney, J.: Detection of a possible change point in atmospheric variability in the North Atlantic and its effect on Scandinavian glacier mass balance, Int. J. Climatol., 25, 18191833, 2005.

Gerbaux, M., Genthon, C., Etchevers, P., Vincent, C., and Dedieu, J. P.: Surface mass balance of glaciers in the French Alps: distributed modelling and sensitivity to climate change, J. Glaciol., 51, 561-572, 2005.

Greene, A., Broecker, W. S., and Rind, D.: Swiss glacier recession since the Little Ice Age: reconciliation with climate records, Geophys. Res. Lett., 26, 1909-1911, 1999.

Haeberli, W.: Glacier fluctuations and climate change detection, Geogr. Fis. Dinam. Quat., 18, 191-199, 1995.

Haeberli, W. and Hoelzle, M. (Compilers): Fluctuations of Glaciers, 1985-1990, vol. 6, UNESCO, Paris, 1993.

Harrison, W. D., Cox, L. H., Hock, R., March, R. S., and Petit, E. C.: Implications for the health of a glacier from comparison of conventional and reference-surface balances, Ann. Glaciol., 50, 25-30, 2009.

Hock, R.: A distributed temperature-index ice- and snowmelt model including potential direct solar radiation, J. Glaciol., 45, 101-11, 1999.

Hock, R.: Temperature index melt modelling in mountain areas, J. Hydrol., 282, 104-115, doi:10.1016/S0022-1694(03)00257-9, 2003.

Hurrell, J. W.: Decadal trends in the North Atlantic Oscillation: Temperatures and precipitation, Science, 269, 676-679, 1995.

Huss, M. and Bauder, A.: Twentieth-century climate change inferred from long-term point observations of seasonal mass balance, Ann. Glaciol., 50, 207-214, 2009.

Huss, M., Funk, M., and Ohmura, A.: Strong Alpine glacier melt in the 1940's due to enhanced solar radiation, Geophys. Res. Lett., 36, L23501, doi:10.1029/2009GL040789, 2009.

Huss, M., Hock, R., Bauder, A., and Funk, M.: 100-year mass changes in the Swiss Alps linked to the Atlantic Multidecadal Oscillation, Geophys. Res. Lett., 37, L10501, doi:10.1029/2010GL042616, 2010.

Huss, M., Hock, R., Bauder, A., and Funk, M.: Conventional versus reference-surface mass balance, J. Glaciol., 58, 278-286, 2012.

Intergovernmental Panel on Climate Change (IPCC): Climate Change 2007, Contribution of the Working Group I to the Third Assessment Report of the Intergovernmental Panel on Climate Change, edited by: Solomon, S., Qin, D., Manning, M., Chen, Z., Marquis, M., Averyt, K. B., Tignor, K. B., and Miller, H. L., Cambridge University Press, New York, pp. 996, 2007.

Johannesson, T., Raymond, C., and Waddington, E.: Time-scale for adjustment of glaciers to changes in mass balance, J. Glaciol., 35, 355-369, 1989.

Jones, P. D., Jonsson, T., and Wheeler, D.: Extension to the North Atlantic Oscillation using early instrumental pressure observations from Gibraltar and South-West Iceland, Int. J. Climatol., 17, 1433-1450, 1997.

Laumann, T. and Reeh, N.: Sensitivity to climate change or the mass balance of glaciers in southern Norway, J. Glaciol., 39, 656-665, 1993.

Lliboutry, L.: Multivariate statistical analysis of glacier annual balances, J. Glaciol., 13, 371-392, 1974.

Maisch, M.: The long-term signal of climate change in the Swiss Alps: Glacier retreat since the end of the Little Ice Age and future ice decay scenarios, Geogr. Fis. Dinam. Quat., 23, 139-151, 2000.

Marzeion, B. and Nesje, A.: Spatial patterns of North Atlantic Oscillation influence on mass balance variability of European glaciers, The Cryosphere, 6, 661-673, doi:10.5194/tc-6-6612012, 2012.

McCabe, G. J. and Wolock, D. M.: Long-term variability in Northern Hemisphere snow cover and associations with warmer winters, Clim. Change, 99, 141-153, 2010.

Müller, H. and Kappenberger, G.: Claridenfirn-Messungen 19141984, Z. Geogr. Schr., 40, pp. 79, 1991.

Nesje, A., Lie, Ø., and Dahl, S.: Is the North Atlantic Oscillation reflected in Scandinavian glacier mass balance records?, J. Quart. Sci., 15, 587-601, 2000.

Oerlemans, J.: A model for the surface balance of ice masses: Part 1. Alpine glaciers, Z. Gletscherkd. Glazialgeol., 27-28, 63-83, 1993. 
Oerlemans, J.: Glacier and Climate Change, edited by: Balkema, A. A., Lisse, The Netherlands, 148 pp., 2001.

Oerlemans, J. and Fortuin, J. P. F.: Sensitivity of glaciers and small ice caps to greenhouse warming, Science, 258, 115-117, 1992.

Oerlemans, J. and Hoogendoorn, N. C.: Mass-balance gradients and climate change, J. Glaciol., 35, 399-405, 1989.

Oerlemans, J., Anderson, B., Hubbard, A., Huybrechts, P., Jóhannesson, T., Knap, W. H., Schmeits, M., Stroeven, A. P., van de Wal, R. S. W., Wallinga, J., and Zuo, Z.: Modelling the response of glaciers to climate warming, Clim. Dyn., 14, 267-274, 1998.

Oerlemans, J., Giesen, R. H., and Van Den Broeke, M. R.: Retreating alpine glaciers: increased melt rates due to accumulation of dust (Vadret da Morteratsch, Switzerland), J. Glaciol., 55, 729_ 736, 2009

Ohmura, A., Bauder, A., Müller, H., and Kappenberger, G.: Longterm change of mass balance and the role of radiation, Ann. Glaciol., 46, 367-374, 2007.

Osborn, T. J.: Recent variations in the winter North Atlantic Oscillation, Weather, 61, 353-355, 2006.

Paterson, W. S. B.: The physics of glaciers, 3rd edn., ButterworthHeinemann, Oxford, United Kingdom, pp. 496, 1994.

Pellicciotti, F., Helbing, J., Rivera, A., Favier, V., Corripio, J., Araos, J., Sicart, J. E., and Carenzo, M.: A study of the energy balance and melt regime on Juncal Norte Glacier, semi-arid Andes of central Chile, using melt models of different complexity, Hydrol. Process., 22, 3980-3997, 2008.

Perreault, L., Bernier, J., Bobée, B., and Parent, E.: Bayesian change-point analysis in hydrometeorological time series, Part 1, The normal model revisited, J. Hydrol., 235, 221-241, 2000a.

Perreault, L., Bernier, J., Bobée, B., and Parent, E.: Bayesian change-point analysis in hydrometeorological time series, Part 2, Comparison of change-point models and forecasting, J. Hydrol., 235, 242-263, 2000b.

Pohjola, V. L. and Rogers, J. C.: Atmospheric circulation and variations in Scandinavian glacier mass balance, Quat. Res., 47, 2936, 1997.

Quadrelli, R., Lazzeri, M., Cacciamani, C., and Tibaldi, S.: Observed winter Alpine precipitation variability and links with large-scale circulation patterns, Clim. Res., 17, 275-284, 2001.

Rabatel, A., Dedieu, J. P., Thibert, E., Letréguilly, A., and Vincent C.: 25 years (1981-2005) of equilibrium-line altitude and mass-balance reconstruction on Glacier Blanc, French Alps, using remote-sensing methods and meteorological data, J. Glaciol., 54, 307-314, 2008.

Rasmussen, L. A.: Altitude variation of glacier mass balance in Scandinavia, Geophys. Res. Lett., 31, L13401, doi:10.1029/2004GL020273, 2004.

Rasmussen, L. A.: South Cascade Glacier mass balance, 19352006, Ann. Glaciol., 50, 215-220, 2009.

Rasmussen, L. A. and Andreassen, L. M.: Seasonal mass balance gradients in Norway, J. Glaciol., 51, 601-606, 2005.
Reichert, B. K., Bengtsson, L., and Oerlemans, J.: Midlatitude forcing mechanisms for glacier 25 mass balance investigated using general circulation models, J. Climate, 14, 3767-3784, 2001.

Scherrer, S. C. and Appenzeller, C.: Swiss Alpine snow pack variability: major patterns and links to local climate and large scale flow, Clim. Res., 32, 187-199, 2006.

Sicart, J. E., Hock, R., and Six, D.: Glacier melt, air temperature and energy balance in different climates: The Bolivian Tropics, the French Alps, and northern Sweden, J. Geophys. Res., 113, D24113, doi:10.1029./2008JD010406, 2008.

Six, D., Reynaud, L., and Letréguilly, A.: Alpine and Scandinavian glaciers mass balances, their relations with the North Atlantic Oscillation, Comptes Rendus de l'Académie des Sciences, Series IIA, Earth Planet. Sc., 333, 693-698, 2001.

Tanner, M. H.: Methods for the Exploration of Posterior Distributions and Likelihood Functions, Springer-Verlag, Berlin, 220 pp., 1996.

Thibert, E. and Vincent, C.: Best possible estimation of mass balance combining glaciological and geodetic methods, Ann. Glaciol., 50, 112-118, 2009.

Thibert, E., Blanc, R., Vincent, C., and Eckert, N.: Glaciological and volumetric mass balance measurements: Error analysis over 51 years for Glacier de Sarennes, French Alps, J. Glaciol., 54, 522-532, 2008.

Vallinga, J. and van de Wal, R. S. W.: Sensitivity of Rhonegletscher, Switzerland, to climate change: experiments with a one-dimensional flowline model, J. Glaciol., 44, 383-393, 1998.

Vallon, M., Vincent, C., and Reynaud, L.: Altitudinal gradient of mass-balance sensitivity to climatic change from 18 years of observations on Glacier d'Argentière, France, J. Glaciol., 44, 93 96, 1998.

Vincent, C.: Influence of climate change over the 20th century on four French glacier mass balances, J. Geophys. Res., 107, 4375, doi:10.1029/2001JD000832, 2002.

Vincent, C. and Vallon, M.: Meteorological controls on a glacier mass balance: empirical relations suggested by measurements on glacier de Sarennes, France, J. Glaciol., 43, 131-137, 1997.

Vincent, C., Kappenberger, G., Valla, F., Bauder, A., Funk, M., and Le Meur, E.: Ice ablation as evidence of climate change in the Alps over the 20th century, J. Geophys. Res., 109, D10104, doi:10.1029/2003JD003857, 2004.

Wanner, H., Brönnimann, S., Casty, C., Gyalistras, D., Luterbacher, J., Schmutz, C., Stephenson, D. B., and Xoplaki, E.: North Atlantic Oscillation - concepts and studies, Surv. Geophys., 22, 321-381, 2001.

Washington, R., Hodson, A., Isaksson, E., and MacDonald O.: Northern hemisphere teleconnection indices and the mass balance of Svalbard glaciers, Int. J. Climatol., 20, 473-487, 2000.

Zemp, M., Hoelzle, M., and Haeberli, W.: Distributed modelling of the regional climatic equilibrium line altitude of glaciers in the European Alps, Global Planet. Change, 56, 83-100, 2007. 